\title{
New haplochromine cichlid from the upper Miocene (9-10 MYA) of Central Kenya
}

\author{
Melanie Altner ${ }^{1 *}$, Bernhard Ruthensteiner ${ }^{2}$ and Bettina Reichenbacher ${ }^{1,3}$
}

\begin{abstract}
Background: The diversification process known as the Lake Tanganyika Radiation has given rise to the most speciose clade of African cichlids. Almost all cichlid species found in the lakes Tanganyika, Malawi and Victoria, comprising a total of 12-16 tribes, belong to this clade. Strikingly, all the species in the latter two lakes are members of the tribe Haplochromini, whose origin remains unclear. The 'out of Tanganyika' hypothesis argues that the Haplochromini emerged simultaneously with other cichlid tribes and lineages in Lake Tanganyika, presumably about 5-6 million years ago (MYA), and that their presence in the lakes Malawi and Victoria and elsewhere in Africa today is due to later migrations. In contrast, the 'melting pot Tanganyika hypothesis' postulates that Haplochromini emerged in Africa prior to the formation of Lake Tanganyika, and that their divergence could have begun about 17 MYA. Haplochromine fossils could potentially resolve this debate, but such fossils are extremely rare.

Results: Here we present a new fossil haplochromine from the upper Miocene site Waril (9-10 million years) in Central Kenya. Comparative morphology, supported by Micro-CT imaging, reveals that it bears a unique combination of characters relating to dentition, cranial bones, caudal skeleton and meristic traits. Its most prominent feature is the presence of exclusively unicuspid teeth, with canines in the outer tooth row.

tWarilochromis unicuspidatus gen. et sp. nov. shares this combination of characters solely with members of the Haplochromini and its lacrimal morphology indicates a possible relation to the riverine genus Pseudocrenilabrus. Due to its fang-like dentition and non-fusiform body, $+W$. unicuspidatus gen. et sp. nov. might have employed either a sit-and-pursue or sit-and-wait hunting strategy, which has not been reported for any other fossil haplochromine cichlid.

Conclusions: The age of the fossil (9-10 MYA) is incompatible with the 'out of Tanganyika' hypothesis, which postulates that the divergence of the Haplochromini began only 5-6 MYA. The presence of this fossil in an upper Miocene palaeolake in the Central Kenya Rift, as well as its predatory lifestyle, indicate that Haplochromini were already an important component of freshwater drainages in East Africa at that time.
\end{abstract}

\section{Background}

Cichlidae are one of the most species-rich freshwater fish families, with about 1700 valid species having been recognized to date $[1,2]$, but their estimated species number may be as high as 3000-4000 [3]. They have

\footnotetext{
* Correspondence: m.altner@lrz.uni-muenchen.de

'Department of Earth and Environmental Sciences, Paleontology and Geobiology, Ludwig-Maximilians-Universität München, Richard-Wagner-Strasse 10, 80333 Munich, DE, Germany Full list of author information is available at the end of the article
}

been intensively studied and are especially famous for their capacity for rapid adaptive speciation (e.g., [4-8]). The most remarkable example of this ability is found in the Great Lakes of the East African Rift System, i.e. Lake Tanganyika, Lake Malawi and Lake Victoria, and is referred to as the 'Lake Tanganyika Radiation' or 'East African Radiation' (e.g., [3, 9-11]). Depending on the author consulted, the Lake Tanganyika Radiation comprises 12 to 16 tribes or lineages ([12, 13]; Fig. 1), most of them are endemic to the Great Lakes. Exceptions are

(C) The Author(s). 2020 Open Access This article is licensed under a Creative Commons Attribution 4.0 International License, which permits use, sharing, adaptation, distribution and reproduction in any medium or format, as long as you give appropriate credit to the original author(s) and the source, provide a link to the Creative Commons licence, and indicate if changes were made. The images or other third party material in this article are included in the article's Creative Commons licence, unless indicated otherwise in a credit line to the material. If material is not included in the article's Creative Commons licence and your intended use is not permitted by statutory regulation or exceeds the permitted use, you will need to obtain permission directly from the copyright holder. To view a copy of this licence, visit http://creativecommons.org/licenses/by/4.0/ The Creative Commons Public Domain Dedication waiver (http://creativecommons.org/publicdomain/zero/1.0/) applies to the data made available in this article, unless otherwise stated in a credit line to the data. 


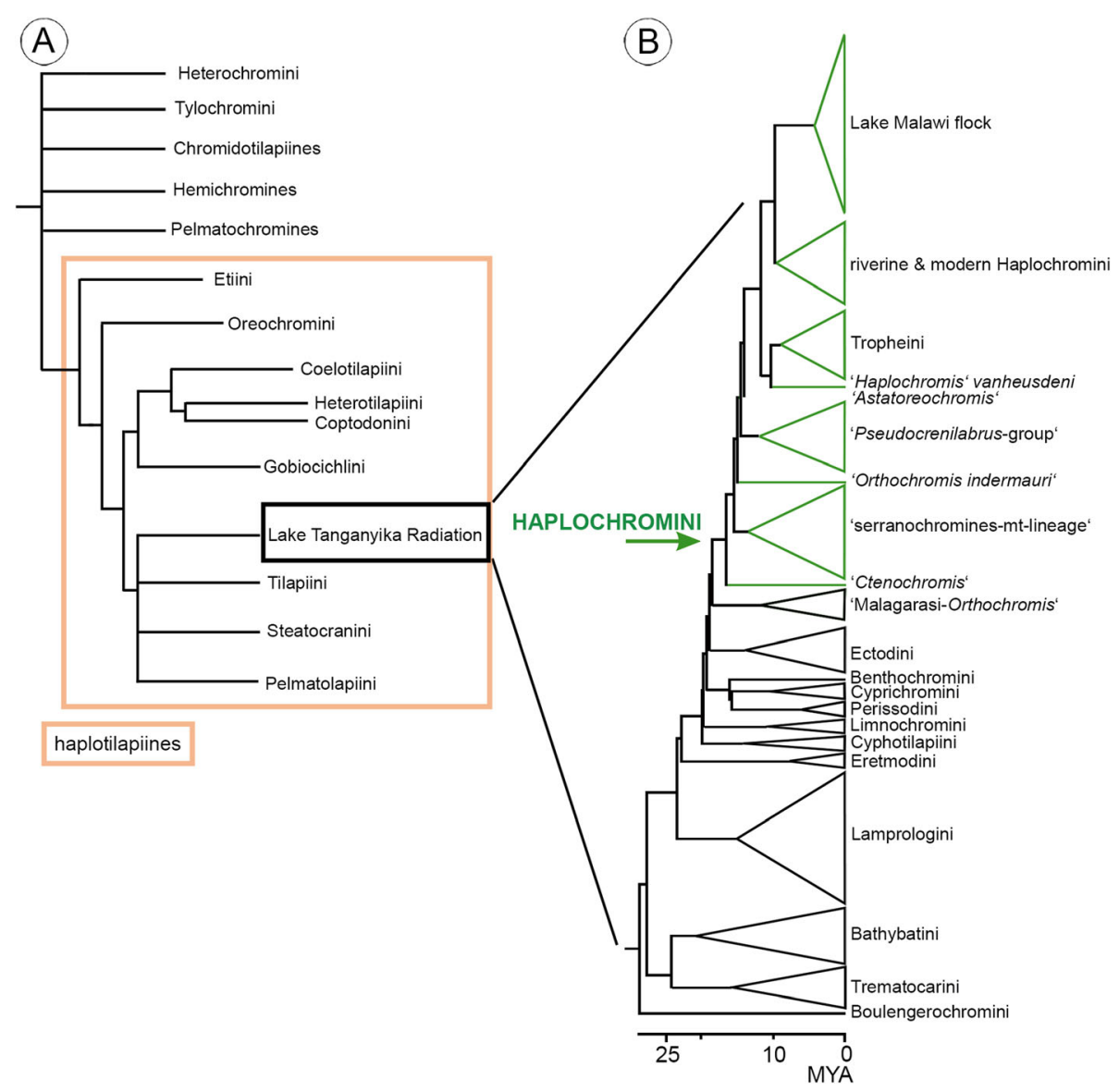

Fig. 1 a Simplified composite phylogenetic tree depicting possible relationships among the Pseudocrenilabrinae, based on Schwarzer et al. [14] and Dunz and Schliewen [15] (reused with slight modifications from Altner et al., [16] (open access article distributed under CC-BY-NC-ND 4.0 license; https://creativecommons.org/licenses/by-nc-nd/4.0/)); b Time calibrated phylogeny of all lineages comprising the Lake Tanganyika Radiation (re-drawn after Schedel et al., [17] distributed under CC-BY license (https://creativecommons.org/licenses/by/4.0/), simplified, error bars for ages of nodes not shown). The area of each triangle corresponds to the number of species used in the original publication; all lineages of the Haplochromini are depicted in green

members of the tribe Lamprologini, which are also represented in rivers across East and Central Africa [18-20], and species of the tribe Haplochromini, which are distributed in rivers and lakes all over Africa, but reach their highest levels of diversity in Lakes Victoria and Malawi (e.g., [18, 21-24]).

With about 1700 species, the Haplochromini is the most speciose of the groups that contributed to the Lake Tanganyika Radiation (see [25]). The tribe can be subdivided into several lineages, of which the flock found in Lake Victoria and the neighbouring lakes (Edward, George and Kivu) is considered to be a superflock [26] (Fig. 1b; see also [17] and [27]). In addition, all Haplochromini are maternal mouthbrooders and have evolved numerous specialized adaptations and feeding strategies (e.g., [28-30]). The Haplochromini that are endemic to Lake Tanganyika, i.e. the Tropheini, are either herbivores (e.g., [31]) or insectivores [32-34], but the haplochromine species of Lake Malawi and Victoria display the full range of feeding specializations from 'Aufwuchs' feeding (grazing on algal communities that are attached to rocks) through insectivory, plankton-feeding, piscivory, herbivory, mollusc-feeding and death feigning to lepidophagy and paedophagy (e.g., [35-40]).

Even though the Haplochromini have been the subject of a very large number of studies dealing with their ecology, behavior or trophic specializations (e.g., [41-44]), many issues remain to be resolved. One of the central questions concerns the evolutionary history of the Haplochromini. Two contrasting hypotheses have been proposed. One theory postulates that the Haplochromini originated within Lake Tanganyika, presumably about 5-6 MYA [25, 45]. The other suggests that the emergence of the tribe predates the formation of Lake Tanganyika (the 'melting pot Tanganyika' hypothesis of Weiss et al. [46]) and that their divergence age could be as old as 17 MYA (see [17] and Fig. 1b). This second hypothesis is compatible with the proposal that at least 
four different riverine lineages of Haplochromini (Tropheini, Pseudocrenilabrus, Astatoreochromis, and Astatotilapia) have independently colonized Lake Tanganyika (see [11]). In addition, the phylogenetic reconstruction by Schedel et al. [17] shows that the closest extant relatives of the Haplochromini all live in habitats that lie to the east of Lake Tanganyika: Four species of the paraphyletic genus Orthochromis, which are sister to the Haplochromini, thrive in the Malagarasi river system, while Ctenochromis pectoralis, which is sister to the remaining Haplochromini, is endemic to drainage systems in Kenya and Tanzania (see Fig. 1b). Thus, the authors suggest that the most recent common ancestor of the Haplochromini must have lived east of Lake Tanganyika.

Fossil cichlids have the potential to clarify the evolutionary history of the group, because they can provide solid age constraints for a given lineage or tribe, and their biogeographic distribution can provide support for one or other of the competing hypotheses. However, the assignment of a fossil cichlid at the level of tribe has proven to be very difficult, because features of the skeleton may show little variation between tribes. The objective of this study is to present a newly discovered cichlid fossil from the upper Miocene Ngorora Formation (Central Kenya) and to infer some aspects of its feeding strategy.

\section{Geological setting}

The Tugen Hills are part of the eastern branch of the East African Rift System (see e.g., [47-50]). The mountain range extends for about $100 \mathrm{~km}$ from north to south $[51,52]$ and its maximum altitude is around $2400 \mathrm{~m}$. Its thick (up to $3000 \mathrm{~m}$ ) successions of volcanic, fluvial and lacustrine rocks document active volcanism and the development of deep lakes as the result of ongoing rifting activity [53-55]. Today, the rock deposits exposed in the Tugen Hills represent the most complete fossiliferous record of the Miocene-Pliocene Epoch in Africa [52] and have been the focus of many research projects, e.g. dealing with regional climate change (e.g., $[49,56,57])$, vegetation (e.g., [58-62]) and the evolution of mammals and hominids (e.g., [63-67]). References to its fossil fish record are generally restricted to comparatively brief remarks in older publications (e.g., [53, 54, 68-73]). However, this topic has received renewed attention in recent years $[16,55,74-76]$. Most of the newly described fish fossils have been discovered in the 'fossil fish Lagerstätte' of the middle-to-upper Miocene Ngorora Formation (13.3-9 MYA) (see [55]).

\section{Study site}

The fossil specimen described here derives from the Ngorora Formation $(\mathrm{Fm})$ at the site Waril $\left(0^{\circ} 40^{\prime} 56.21^{\prime \prime}\right.$
$\left.\mathrm{N} ; 35^{\circ} 43^{\prime} 7.43^{\prime \prime} \mathrm{E}\right)$. This site is located in a remote area 4 $\mathrm{km}$ south of Barwesa and $8 \mathrm{~km}$ northeast of Kapturwo in Baringo County, Kenya (Fig. 2a). The name 'Waril' derives from a Tugen term meaning 'at the white place' [77] and probably refers to the light colour of the sediments (Fig. 2b-d). The exposed sediments comprise tuffs and claystones and represent a late Miocene palaeolake (9-10 MYA, see [55]). That numerous very well-preserved cichlid fish fossils occur at Waril has been known for a long time [72], but the locality has only recently become the subject of detailed investigations, because new excavations could be undertaken in 2013 and 2014. Among the material recovered, two particular fossil specimens were found to be unique. †Tugenchromis pickfordi Altner, Schliewen, Penk \& Reichenbacher, 2017 has already been described as a stem-group member of the Lake Tanganyika Radiation [16], and the other most striking specimen is presented in this study. The rest of the material is currently under study.

\section{Results}

The fossil presents features which, in combination, are typical for modern cichlid fishes (see [78-84]): an interrupted lateral line; caudal fin skeleton with eight principal fin rays in each lobe, two epural bones, uroneural probably autogenous, autogenous parhypural, preural centrum 2 with autogenous haemal spine and reduced neural spine, haemal spine of preural centrum 3 not autogenous; presence of five branchiostegals; single dorsal fin consisting of spines and rays; pelvic fin with one spine and five rays (for details see below).

There is no unambiguous synapomorphy known for the subfamily Pseudocrenilabrinae. The putative synapomorphy 'strongly pigmented opercular spot', proposed by Stiassny [85], is not present in Heterochromis - and would not be recognizable in a fossil in any case. A 'simple sutural union between the vomerine wing and the parasphenoid' was identified as typical for the Pseudocrenilabrinae by Stiassny [85], but she already noted that exceptions exist (e.g. Heterochromis). In addition, two members of the subfamily Ptychochrominae, i.e. Ptychochromis and Paratilapia, and some members of the subfamily Etroplinae possess this character [85]. On inspection of the morphological data matrix compiled by Stiassny [85], the character 'single supraneural' appears to be a putative synapomorphy for the Pseudocrenilabrinae, but this character also occurs in the Neotropical cichlids (Cichlinae) (see e.g. Kullander, [86]).

To tentatively assign the new fossil to one of the subfamilies of the Cichlidae we carried out a maximumparsimony analysis of the matrix based on Stiassny [85] using implied weighting $(K=12.0)$. The resulting single most parsimonious tree (MPT) is shown in Fig. 3. This 

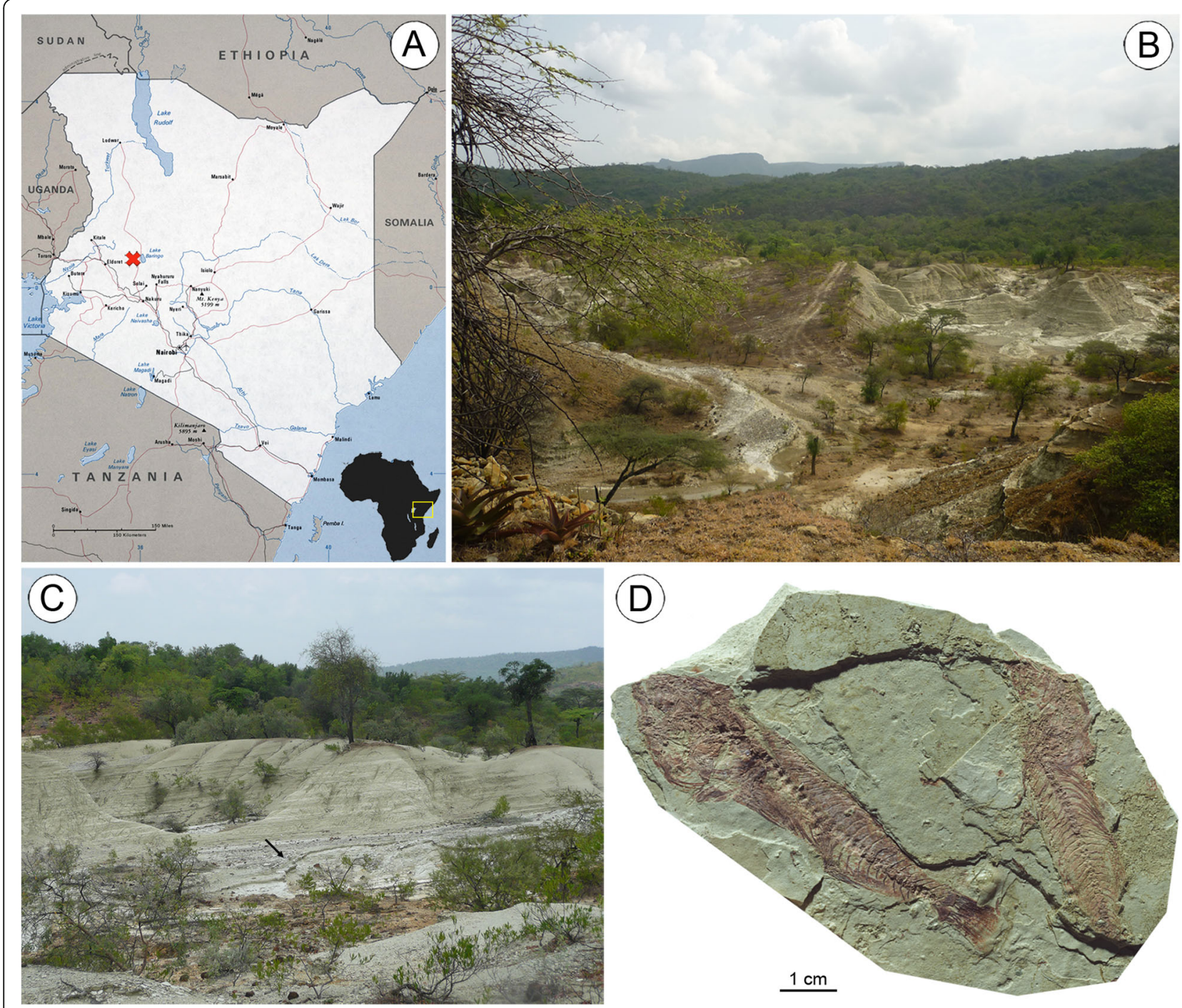

Fig. 2 a Location of the fossiliferous beds at the Waril site (red cross) in Kenya (source of map: copyright 2019 Mapsland; mapsland.com with terms of Creative Commons Attribution-shareAlike 3.0 license [CC BY-SA 3.0] https://creativecommons.org/licenses/by-sa/3.0/); b-c Upper Miocene lacustrine sediments exposed at Waril (arrow in c points to fish-bearing layer); $\mathbf{d}$ Example of sediment block containing fish fossils (OCO-5-13). Photos $\mathbf{b}$ and $\mathbf{c}$ were taken by first author, photo $\mathbf{d}$ by M. Schellenberger (SNSB-BSPG, Bavarian State Collection Palaeontology and Geology, Munich, Germany). Copyright (2020), with permission from SNSB - BSPG

tree shows a higher resolution than the original phylogeny of Stiassny [85], which is probably due to the use of implied weighting. If the analysis is run with all characters set unweight, three MPTs are obtained and the resulting consensus tree matches exactly the original tree by Stiassny [85]. Stiassny's Ptychochromines emerges as sister to all Cichlidae, the Etroplinae (Stiassny's Etroplines) are sister to all Cichlidae except the Ptychochrominae (Stiassny's Ptychochromines + Paratilapia), and Heterochromis is sister to all Cichlidae except the Ptychochrominae and Etroplinae (=Madagascan and Indian taxa). The relationships within the Cichlinae (Neotropical cichlids) are resolved with moderate support (this clade was polyphyletic in the original tree obtained by
Stiassny, [85]). Also, the clade comprising the Pseudocrenilabrinae except Heterochromis is resolved, albeit with low support. The new fossil specimen is placed within the latter clade (including the African cichlids Tylochromis, Hemichromines, Chromidotilapiines, Pelmatochromis, Lamprologines and 'The Rest') with low support and is sister to all African cichlids except Tylochromis and Heterochromis.

\section{SYSTEMATIC PALAEONTOLOGY.}

SERIES OVALENTARIA Wainwright et al., 2012.

SUPERORDER CICHLOMORPHAE Betancur-R. et al., 2013.

ORDER CICHLIFORMES Nelson et al., 2016.

FAMILY CICHLIDAE Bonaparte, 1835. 


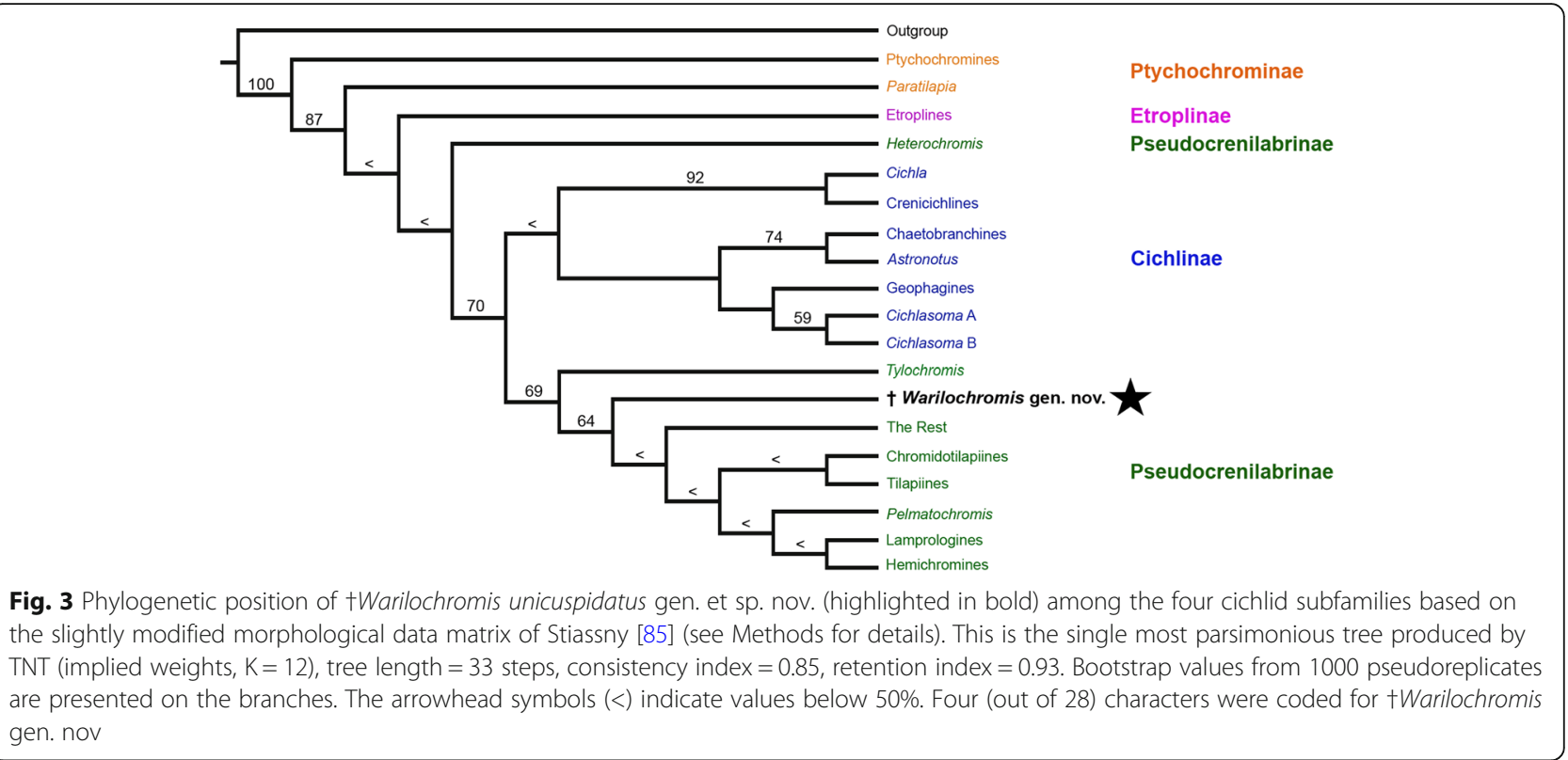

SUBFAMILY PSEUDOCRENILABRINAE Fowler, 1934. GENUS +WARILOCHROMIS gen. nov.

Zoobank Nr.: LSID urn:lsid:zoobank.org:act:FD3D44E6A313-4809-8FDF-46850A20B5E1.

Generic Diagnosis-†Warilochromis differs from all other fossil and extant cichlids in a unique combination of characters comprising the following: four lateral-line tubules on the lacrimal bone; ascending process of premaxilla shorter than horizontal ramus; oral dentition unicuspid with large canines in the outer row and smaller teeth in the inner row; one supraneural bone; $33(19+14)$ vertebrae; vertebra 17 associated with pterygiophore of last dorsal fin spine; three anal fin spines; hypural $1+2$ fused and autogenous, hypural $3+4$ fused and probably fused to terminal centrum; divided lateral line; cycloid scales.

Etymology - Name refers to the locality Waril where the fossil was found. The Greek word 'Chromis' ( $\mathrm{xpó} \mu \mathrm{s}$ ) is a name used by the Ancient Greeks and has been applied to various fish. It is a common second element in cichlid genus names.

Type Species-†Warilochromis unicuspidatus sp. nov.

†WARILOCHROMIS UNICUSPIDATUS sp. nov.

Holotype-2014-WA-16. Skeleton preserved in left lateral view; total length $8.2 \mathrm{~cm}$, standard length $6.9 \mathrm{~cm}$, and body length approximately $4.6 \mathrm{~cm}$. Bones of skeleton almost completely preserved, with exception of the first four abdominal vertebrae, caudal vertebrae 4-6, and preural centrum 2 of which only imprints are visible. For taphonomic reasons, the long axis of the specimen is shortened.

Diagnosis-Same as for the genus.

Etymology-The specific name 'unicuspidatus' refers to the latin words 'unus' = one and 'cuspis' = point, to emphasize the conspicuous dentition of the oral jaws.
Type locality and age-Kenya, Tugen Hills, Ngorora basin, Ngorora Formation, Member E, site Waril $\left(0^{\circ} 40^{\prime}\right.$ $\left.56.21^{\prime \prime} \mathrm{N} ; 35^{\circ} 43^{\prime} 7.43^{\prime \prime} \mathrm{E}\right)$, ca. 9-10 Ma.

\section{Description \\ General description}

Approximately $82 \mathrm{~mm}$ in total length and $69 \mathrm{~mm}$ in standard length (SL) (see Table 1). Greatest body depth behind head. Stout body with relatively short but narrow caudal peduncle. Body approximately straight although posterior part of vertebral column is bent upwards slightly (Fig. 4). Large skull (head length $33.3 \%$ of SL), terminal snout, probably isognathous jaws, oral dentition unicuspid. Divided lateral line.

\section{Neurocranium and infraorbital series}

Outline of neurocranium gently ascending, straight above orbit and slightly convex above supraoccipital crest. Supraoccipital crest low. Frontals unclear, but neurocranial lateral-line canals partially visible (Figs. 4, and Fig. 5a1-3). Massive, straight parasphenoid, broken posteriorly; vomer partially preserved; suture between vomer and parasphenoid simple, not notched (Figs. 5a1-a3).

Infraorbital series comprises the lacrimal (first infraorbital $=$ IO1) (Figs. 5a1-3). Other infraorbital bones are not recognizable, either because the adjacent infraorbi$\operatorname{tal}(\mathrm{s})$ were reduced or because they were lost during fossilization. Lacrimal presents four lateral-line tubules and no scale cover (Figs. 5a1-3).

\section{Oral jaws and teeth}

Premaxilla slender with ascending process approximately $75 \%$ of the length of horizontal ramus $(5.6 \mathrm{~mm}$ vs. $7.2 \mathrm{~mm}$; 
Table 1 Morphometric and meristic data for +Warilochromis gen. nov

\begin{tabular}{|c|c|c|c|}
\hline Measurement & $\mathrm{mm} / \%$ of $\mathrm{SL}$ & Counts & \\
\hline Total length & $81.9 / 118.8$ & Dorsal fin & $\mathrm{XIV}, 10$ \\
\hline Standard length & 68.9 & Anal fin & III, 9 \\
\hline Body length & $45.9 / 66.6$ & Pelvic fin & 1,5 \\
\hline Head length & 22.9/33.3 & Caudal fin & $4+i+7+7+i+5$ \\
\hline Head depth & 23.3/33.8 & Vertebrae & $33(19+14)$ \\
\hline Length of dorsal fin base & $31.1 / 45.2$ & VtPtLDs & 17 \\
\hline Length of anal fin base & $12.1 / 17.5$ & & \\
\hline Length of pelvic fin base & $3.5 / 5.0$ & & \\
\hline Length of pelvic fin spine & 10.0/14.6 & & \\
\hline Length of caudal fin & $16.0 / 23.2$ & & \\
\hline Maximum body depth & $21.7 / 31.4$ & & \\
\hline Depth of body at anal fin & $19.6 / 28.4$ & & \\
\hline Minimum body depth & $8.6 / 12.5$ & & \\
\hline Predorsal distance & $27.5 / 39.9$ & & \\
\hline Postdorsal distance & $23.2 / 33.7$ & & \\
\hline Preanal distance & $44.3 / 64.3$ & & \\
\hline Length of caudal peduncle & $13.4 / 19.5$ & & \\
\hline Prepelvic distance & $23.4 / 33.9$ & & \\
\hline Length of lower oral jaw & $9.8 / 14.3$ & & \\
\hline Length of premaxillary ascending process & $5.6 / 8.2$ & & \\
\hline Length of premaxilla & $7.2 / 10.5$ & & \\
\hline
\end{tabular}

Abbreviation: VtPtLDs Ordinal number of the vertebra associated with pterygiophore of last dorsal fin spine

see Table 1); left horizontal ramus visible as imprint, right horizontal ramus preserved in medial view with teeth in situ. Recognizable teeth comprise (i) three large canines (length $0.7-1.1 \mathrm{~mm}$ ) of which the two anteriormost ones are preserved in labial view and do not show lateral compression (Fig. 5b); (ii) a small unicuspid tooth (length 0.4 $\mathrm{mm}$ ) positioned slightly medial to the largest teeth (indicated by the arrow in Fig. 5b); (iii) a small unicuspid tooth (length $0.2 \mathrm{~mm}$ ) at the beginning of the distal third of the bone (Fig. 5a3). Left maxilla as long as ramus of premaxilla, head with robust neurocraniad process, remainder of bone with straight anterior but expanded posterior margin, the latter with marked dorsal wing. Right dentary preserved in medial view, robust; lower arm probably of same length as upper arm, but deeper. Teeth of dentary comprise at least three large canines (length $0.6-0.7 \mathrm{~mm}$ ) in the anterior part and several smaller (length $0.2-0.5 \mathrm{~mm}$ ) unicuspid teeth lying medial to the larger teeth up to the distalmost quarter of the bone (Figs. 5a3, c). The enlarged canines on the anterior tip of the premaxilla and the dentary represent outer row teeth and the smaller unicuspid teeth in between and medial to these represent the inner row teeth.

Anguloarticular slender-triangular, 1.24x longer than deep, posterior margin with small facet for lateral condyle of quadrate, pointed dorsal process. Retroarticular rather small and triangular and preserved in anatomical connection (Figs. 5a1-3).

\section{Suspensorium and Opercular apparatus}

The suspensorial bones are incompletely preserved. Palatine robust and bent, ventrally associated with small, slender ectopterygoid (Figs. 5a1-3). Hyomandibula with long and robust ventral process, large dorsally directed articulation facets; best visible in the Micro-CT data. Opercle crushed, probably relatively large, triangular. Of the subopercle only a long and pointed subopercular process is recognizable based on the Micro-CT sections, and runs parallel to the anteroventral margin of the opercle (Figs. 5a1-2). Interoperculum not preserved. Preopercle (?) robust, crescent-shaped, at least three lateral-line tubules recognizable ventrally; horizontal limb broad; vertical limb incomplete, but probably narrower. It is not absolutely clear whether this bone actually represents the preopercle. Due to the presence of lateral-line tubules, it could also be the second lacrimal but, judging from its position, it is more likely to correspond to the preopercle.

\section{Hyoid and branchial arches}

Anterior portion of left and right hyoid bars including the dorsal (?) and ventral hypohyals partly preserved; the 

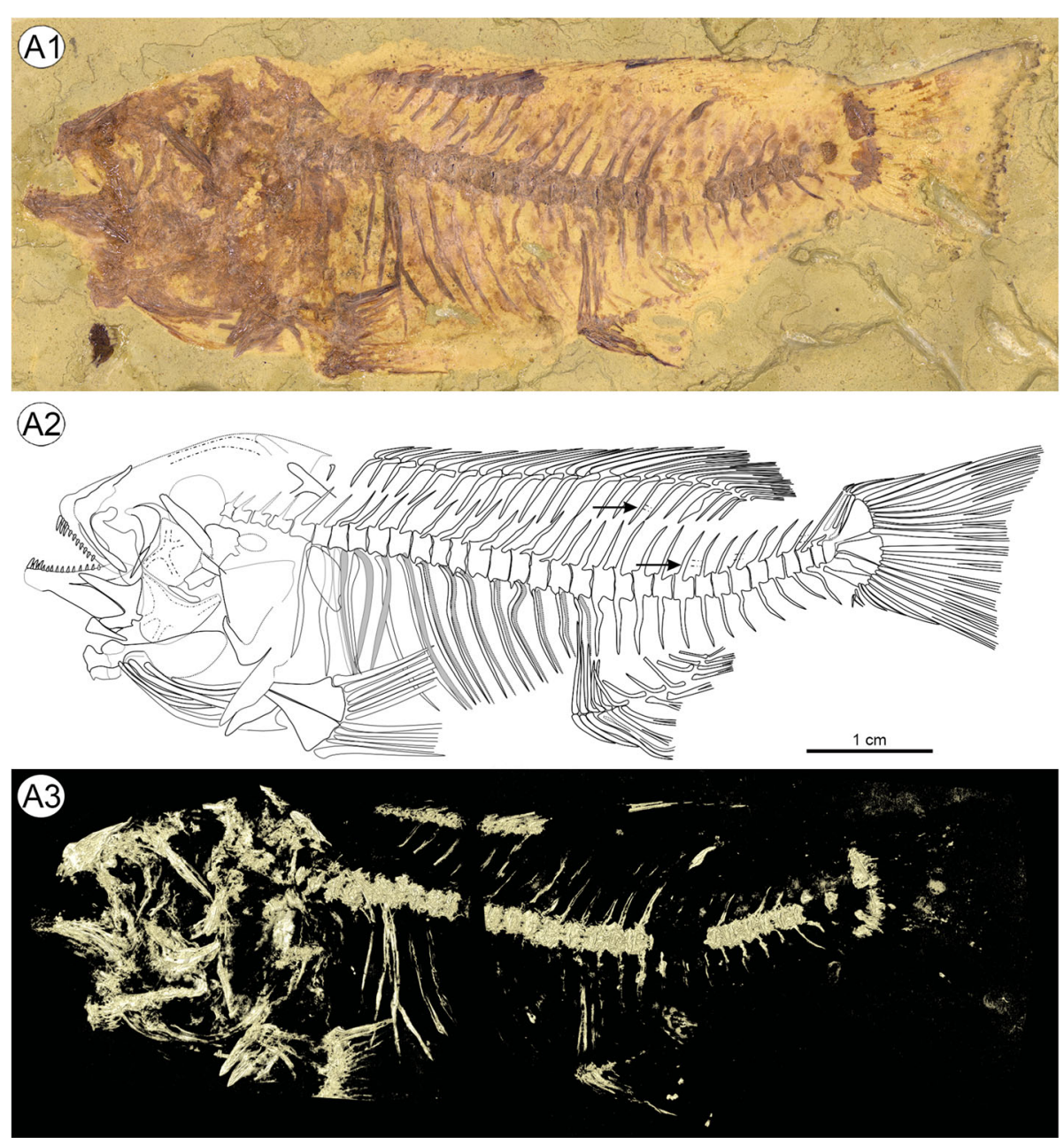

Fig. 4 Holotype and single specimen of + Warilochromis unicuspidatus gen. et sp. nov. a1, Photograph of specimen; a2, Interpretative drawing (arrows refer to lateral-line canals of the anterior and posterior lateral-line segments); a3, Micro-CT rendering revealing the side of the fossil that was embedded in the sediment (mirrored for ease of comparison). Note that the specimen is distorted and shortened along the anteriorposterior axis for taphonomic reasons. This has led to the displacement of the anteriormost vertebrae and distortion of the shape of the orbit. Photographs by first author

border between the dorsal and ventral hypohyal and where they meet the anterior ceratohyal is not clearly visible. Ventral hypohyals robust, bearing a posteroventrally directed spine. Anterior ceratohyal abruptly becoming more slender towards the midline (Figs. 5a1-3). Basihyal triangular, recognizable between ceratohyals and dentary. Five branchiostegal rays can be discerned on the right side and at least two are visible on the left (Figs. 4, 5a1-3). Pharyngeal teeth bicuspid (with prominent cusp and shoulder), mostly slender, interspersed with broader bicuspid teeth (with one prominent and one minor cusp) (marked with an arrow in Fig. 5a1).

\section{Vertebral column}

Vertebral column slightly concave in the caudal region, 33 vertebrae, 19 abdominal and 14 caudal (Fig. 4, Table 1). Vertebral centra higher than long, hourglass-shaped, first and penultimate centra shorter than all others. Neural spines increasing in length from anterior to posterior with spines of last abdominal to first three caudal vertebrae longest, decreasing in length towards the caudal fin. Haemal spine of first caudal vertebra located posterior to third anal fin pterygiophore (Fig. 4). Fourteen pairs of long and slender ribs, first pair on fifth vertebra, parapophyses increasing in length posteriorly. No epipleurals recognizable. Supraneural bone club shaped (Figs. 4, 5a3).

\section{Pectoral girdle and fins}

Plate-like bone probably representing supracleithrum present underneath vertebral column (6th vertebra); cleithrum partially preserved, with ventral part pointed (both sides present), dorsal part probably missing; scapula not preserved; coracoid partially preserved in front 

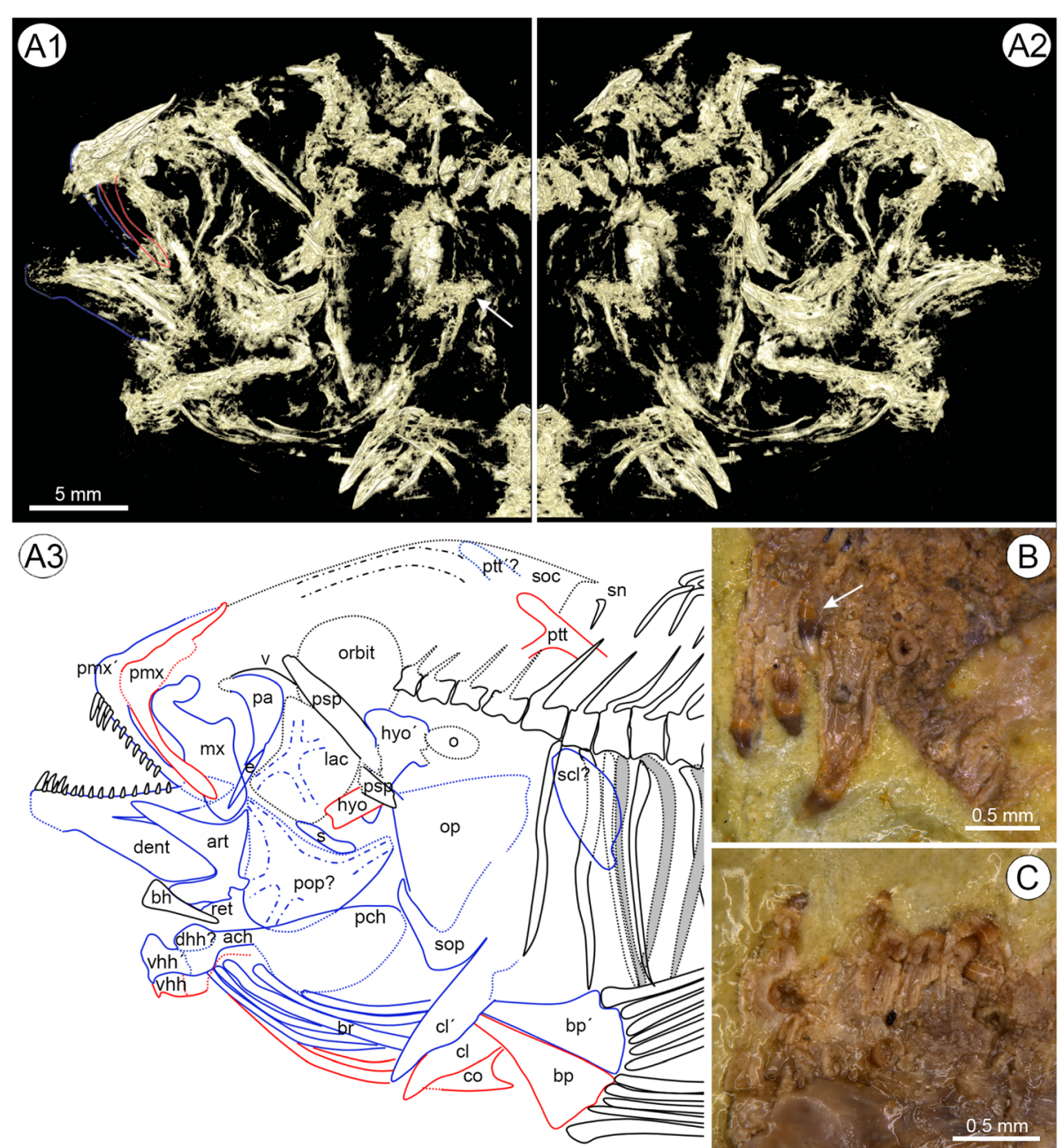

Fig. 5 Head and dentition of $+W$. unicuspidatus gen. et sp. nov. a1-2, Micro-CT renderings; a3, interpretative reconstruction of the head and dentition. The colored lines depict bones that were only recognizable using light microscopy; b, Light microscopical close-up of anterior part of right premaxillary (medial view); note that small conical tooth of the inner row (arrow) lies above large caniniform tooth of the outer row; c, Light microscopical close-up of anterior part of left dentary with conical teeth. Photographs by first author. Abbreviations: ach, anterior ceratohyal; art, angulo-articular; bp \& bp', basipterygium; bh, basihyal; cl \& cl', cleithrum; co, coracoid; dent, dentary; dhh, dorsal hypohyal; e, ectopterygoid; hyo \& hyo', hyomandibula; lac \& lac', lacrimal; $\mathbf{m x}$, maxilla; o, otolith imprint; op, opercle; pa, palatine; pch, posterior ceratohyal; pmx \& pmx', premaxilla; pop, preopercle; psp, parasphenoid, ptt \& ptt', posttemporal; s, symplectic; scl, supracleithrum; sn, supraneural; sop, suboperculum; $\mathbf{v}$, vomer; vhh \& vhh', ventral hypohyal

of cleithrum; no postcleithrum; no pectoral fin discernible (Figs. 4, 5a3). Left posttemporal forked with robust dorsal process, ventral process seems more slender, but anteriorly broken. Probable dorsal process of right posttemporal preserved dorsally to left bone (Fig. 5a).

\section{Pelvic girdle and fins}

Basipterygia elongate, triangular plates that broaden posteriorly. Each pelvic fin with one strong spine and five branched, segmented rays, probably not reaching anal fin origin (Figs. 4, 5a1-3).

\section{Dorsal fin}

Dorsal fin continuous, 14 spines and 10 branched, segmented rays. Spines increase in length posteriorly. Rays do not reach posterior margin of hypural plates. 22 stout pterygiophores (last one supporting two rays), decreasing in length posteriorly; pterygiophore of last fin spine inserts behind neural spine of 17 th vertebra. Pterygiophore of sixth ray thickened (Fig. 4).

\section{Anal fin}

Anal fin with 3 strong spines and 9 branched, segmented rays. Spines gradually increase in length. Rays reach the first third of caudal peduncle. Twelve pterygiophores in 
total, decreasing in size posteriorly; anteriormost three pterygiophores insert before last abdominal vertebra (Fig. 4). First two pterygiophores are fused, but their size proportions differ from that seen in recent cichlids as the first pterygiophore is longer than the second one, rather than shorter. Association between further spines/ rays and pterygiophores unclear.

\section{Caudal skeleton and fin}

The caudal axial skeleton comprises two broad hypural plates; hypural $1+2$ is autogenous, hypural $3+4$ is probably fused to the terminal centrum (urostyle). Hypural plates $1+2$ and $3+4$ show crests in their posterior parts (Fig. 6a1). A small and slender hypural plate 5 is positioned between hypural plate $3+$ 4 and epural 2; it appears to reach the tip of the uroneural. Broad parhypural, located close to hypural $1+2$. Two epurals, but only epural 2 is clearly discernible. Uroneural not distinctly visible, but probably above urostyle and proximal to hypural plate 5 . Neural and haemal spine of preural centrum 3 supporting procurrent rays. Haemal spine of preural centrum 2 autogenous and broad; neural spine of preural centrum 2 probably absent (Fig. 6a).
Caudal fin slightly truncate (Fig. 4a1-2). It consists of $16(8+8)$ segmented principal fin rays, of which the upper and lowermost are unbranched. The principal fin rays are supported by the parhypural, hypural plates $1+$ 2 and $3+4$. Four dorsal and five ventral procurrent rays are present.

\section{Squamation}

Scales preserved in medial view; scale type cycloid. Circuli mostly absent due to irregular granulation, which covers almost the entire scale (including focus; Fig. 6b), especially on flank scales; best recognizable on lateral fields.

Scales cover the whole body except the predorsal part; no scales on head. Approximately 28 scales in longitudinal line. Five or six? scale rows above vertebral column and about eight rows below. Divided lateral line, anterior lateral line about two scale rows below soft-rayed part of dorsal fin (Fig. 4a2) and two scale rows above body axis (= scale row bearing posterior lateral line according to Takahashi, [13]); no overlap (gap of two scales) between anterior and posterior lateral line; lateral-line canals clearly recognizable in one scale of the anterior and three scales of the posterior lateral line (arrows in
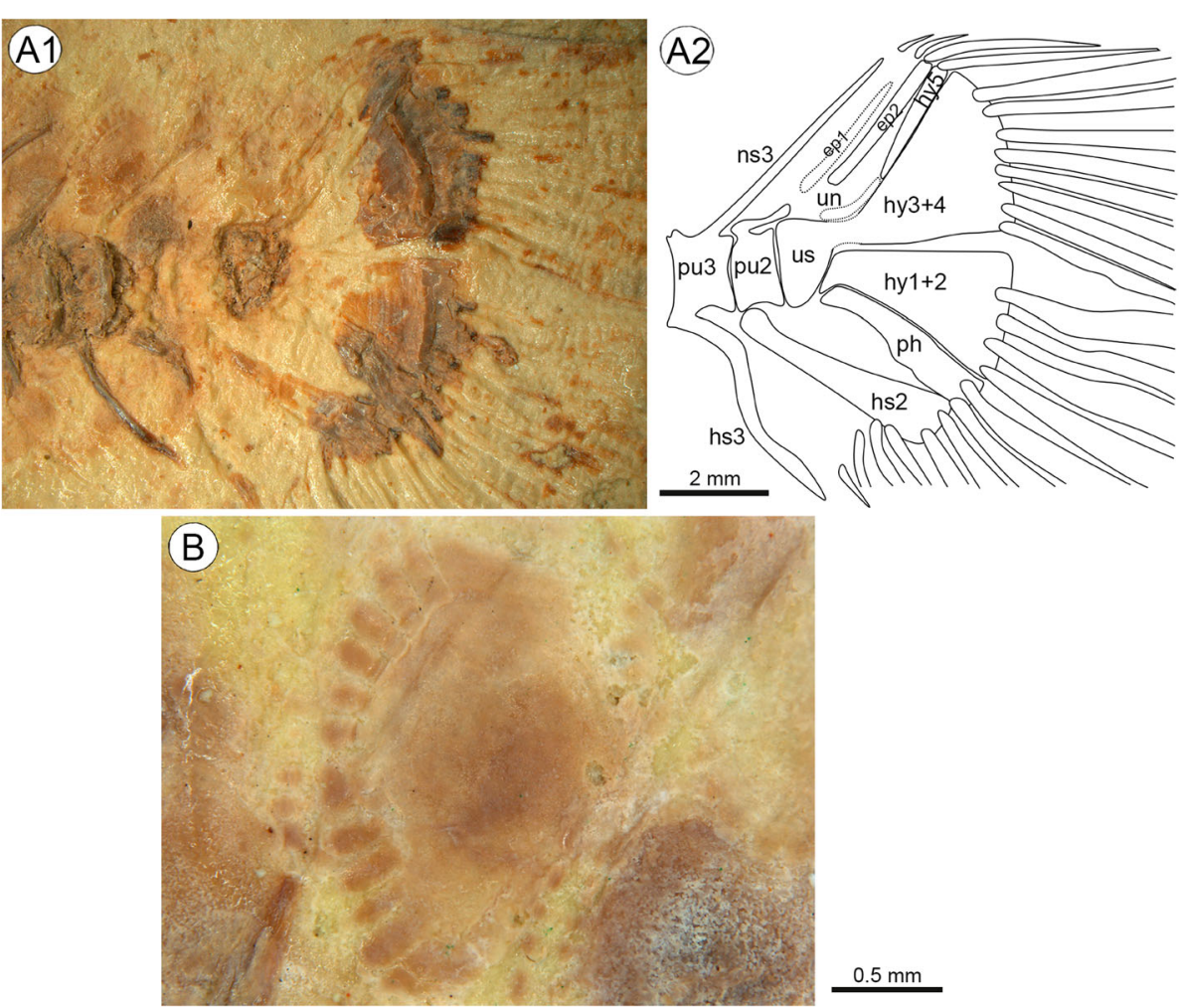

Fig. 6 A, Caudal fin endoskeleton of $+W$. unicuspidatus gen. et sp. nov. based on light microscopy (a1) and interpretative drawing (a2); b, Closeup of scale (medial view) on dorsal part of caudal peduncle; note that rostral scale field is covered by neural spine. Photographs by first author. Abbreviations: ep1, ep2, epurals; hs, haemal spines; hy1-5, hypural plates; $\mathbf{n s}$, neural spines; ph, parhypural; pu, preural centrum; un, uroneural; us, terminal centrum 
Fig. 4a2); estimated total number of posterior lateral-line scales is at least seven.

Scale shape below dorsal fin and on dorsal part of caudal peduncle trapezoidal and wider than long ( 2.2 $\mathrm{mm}$ width and $1.6-1.7 \mathrm{~mm}$ length; width/length ratio 1.3-1.4) (Fig. 6b). Ventral scales posterior to anal fin more rounded $(1.1 \mathrm{~mm}$ length and $0.9 \mathrm{~mm}$ width). Belly scales not recognizable. Around $11-13$ broad and short radii (Fig. $6 \mathrm{~b}$ ).

\section{Discussion}

\section{The best-fit approach}

In the following, we justify the assignment of + Warilochromis to the pseudocrenilabrine tribes based on application of the 'best-fit approach' [76]. This method is similar to the established taxonomic assignment of fossil taxa, but, compared to previous works, uses a much more comprehensive dataset of extant species to dissect the phylogenetic affinities of the fossil.

The study of our comparative dataset and related published data (e.g., [13, 85, 87, 88]) reveals that the character combination 'single supraneural + exclusively unicuspid oral dentition + a lacrimal with four lateralline tubules' found in +Warilochromis occurs in eight tribes of extant African cichlids - namely Hemichromines, Pelmatochromines, Chromidotilapiines and five tribes of the haplotilapiines, i.e. the Trematocarini, Lamprologini, Cyprichromini, Ectodini and Haplochromini, the latter five belong to the Lake Tanganyika Radiation (Fig. 7; see also Fig. 1).

We argue that + Warilochromis cannot be allocated to the Hemichromines, Pelmatochromines or Chromidotilapiines for the following reasons. (i) +Warilochromis has fused hypural plates (Fig. 6a), and no such fusion is known for species of the Hemichromines or Pelmatochromines (our own data and [78]); and (ii) the shape of the crowns of the outer teeth as seen in labial view in +Warilochromis (Figs. 5b-c) is unlike that reported for the Chromidotilapiines, in which the outer-row teeth have 'a unilaterally compressed cone, the compression being manifest on the labial aspect of the crown' (Greenwood, [87]:158).

Among the five Lake Tanganyika tribes under consideration, we regard +Warilochromis as being clearly

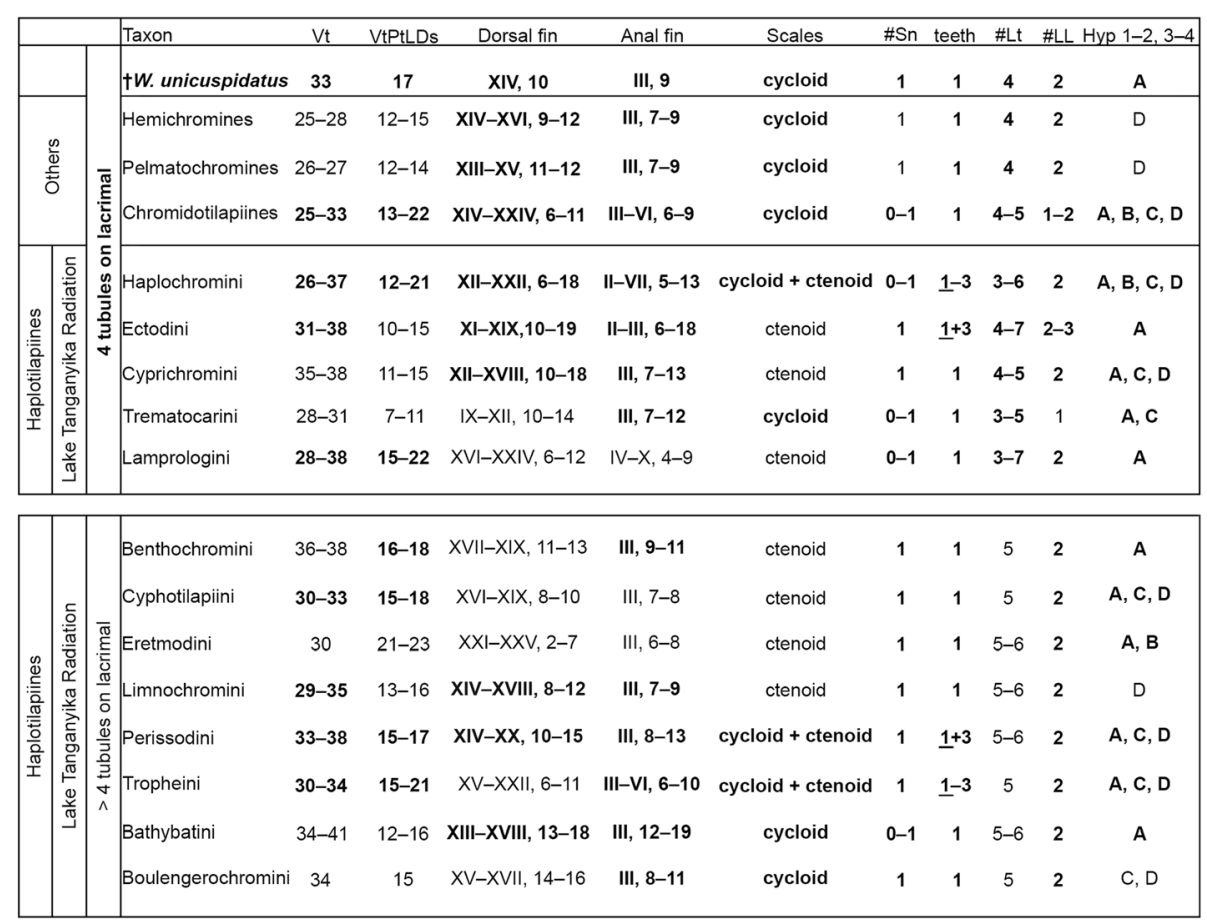

Fig. 7 Morphological characters of +Warilochromis unicuspidatus gen. et sp. nov. and of all modern species of the tribes of the Lake Tanganyika Radiation and three further tribes of the Pseudocrenilabrinae in which the character combination single supraneural + exclusive unicuspid oral dentition (as seen in the fossil) can occur. Abbreviations: Vt, total number of vertebrae; VtPtLDs, ordinal number (s) of vertebrae associated with the pterygiophore of the last dorsal fin spine; scales, predominant scale type on flanks; \#Sn, number of supraneural bones; teeth, inner and outer row teeth of oral dentition coded as follows: 1 = unicuspid, 2 = bicuspid, $3=$ tricuspid, and underlining is used to indicate that exclusively unicuspid dentition is present in some species; \#Lt, number of lateral-line tubules on the lacrimal; \#LL, number of lateral-line segments on the body; Hyp 1-4, configuration of the hypural plates coded as follows: $A=$ hyp $1+2,3+4 ; B=$ hyp $1+2,3,4 ; C=$ hyp 1, 2, 3 + 4; D = hyp 1, 2, 3, 4 . Source of data: comparative material (see Additional file 1: Supplementary Data S1 and Additional file 2: Supplementary Data S2) and literature: [89-189] 
distinct from the Trematocarini and Lamprologini. The Trematocarini do not have a divided lateral line (their posterior lateral-line segment is absent), whereas a divided lateral line is present in +Warilochromis (see Fig. 4a2). In addition, Trematocarini are unique insofar as the pores of the lateral-line tubules on the lacrimal are distinctly larger than the tubule itself, such that adjacent pores are almost in contact (Takahashi, [88]:13-14, Fig. 7). The common condition in cichlids is that the diameter of the sensory pore corresponds to of the lateralline tubule with which it is associated. In +Warilochromis the distal portion of the lateral-line tubules on the lacrimal is clearly discernible and adjacent tubules are widely separated from each other (Figs. 5a1-3). This indicates that the pores must have been further apart than in the Trematocarini, and of 'normal' size. Both features suggest that the new fossil does not exhibit the condition characteristic of the Trematocarini. Finally, †Warilochromis possesses only three anal fin spines (Fig. 4), and therefore differs from all members of the Lamprologini, which have more than three of these elements (Stiassny, [190]).

The three remaining candidate tribes to which + Warilochromis could belong based on this comparative approach are the Cyprichromini, Ectodini and Haplochromini. They share the following suite of features with +Warilochromis: a single supraneural bone, exclusively unicuspid oral dentition with normally shaped crowns, lacrimal with four lateral-line tubules, posterior lateral-line segment present, three anal fin spines and hypural plates $1+2$ and $3+4$ fused (see Fig. 7).

Among the character combination that defines the Cyprichromini are the following traits: fusiform elongated body (4 to $4.65 \mathrm{x}$ longer than high); minute and subconical pharyngeal teeth forming a comb-like row on the posterior border, with the rest of the pharyngeal bone being sparsely dentigerous; an emarginate caudal fin; strongly ctenoid scales; and 35-36 $(17+18-19)$ vertebrae [12]. According to Takahashi's [13] work, the members of this tribe can be recognized by the presence of the 'neurocranial lateral-line foramen 0' that is 'separated from its opposite member', a 'forked caudal fin, and ctenoid scales at mid-body' (Takahashi, [13]:377). It is unlikely that +Warilochromis represents a member of the Cyprichromini in light of its more compact body proportions (3.8x longer than high), bicuspid pharyngeal teeth that seem to have been evenly distributed on the pharyngeal jaws, slightly truncate caudal fin, cycloid scales, and fewer vertebrae $(33(19+14))$.

The character combination that defines the tribe Ectodini includes the presence of exclusively ctenoid scales and an emarginate caudal fin [12], as well as a unique morphology of the palatine (with the posterior and dorsal margins forming a $90^{\circ}$ angle) $[191,192]$. In addition, Takahashi [13] proposed as synapomorphies for the
Ectodini the presence of infraorbitals of type B (IO1 posteriorly elongated, opening through 4-7 pores, IO2-4 continuous, IO2 with 4-5 pores, IO3 + IO4 short; see [88] for details) and a palatopterygoid gap. Clearly, given its cycloid scales, truncate caudal fin and palatine morphology, + Warilochromis cannot be a member of the Ectodini.

Poll [12] defined the Haplochromini as having a rounded or subtruncate caudal fin; at least partially cycloid scales; bicuspid (or partially unicuspid) outer-row and tricuspid inner oral dentition; bicuspid, conical or molariform pharyngeal teeth; a dorsal fin with 13-20 spines and 8-11 rays; an anal fin with 3-6 spines and 7-10 rays; and the presence of 28-35 scales in the longitudinal line. Takahashi [13] revised this diagnosis and proposed the combination of type A infraorbitals (= composed of six elements, lateral line on lacrimal (IO1) branched into five tubules; sensu Takahashi, [88]); bicuspid outer and tricuspid inner teeth on both jaws; and ctenoid scales at midbody as diagnostic for this tribe. However, it should be noted that exceptions to several of these characters are known. (i) Not all species of the riverine genus Pseudocrenilabrus display five lateral-line tubules on the lacrimal: the number can vary from 3 to 6 , with a modal number of 4 [127]; (ii) piscivorous species of Haplochromis in Lake Victoria and the riverine Serranochromines have unicuspid inner- and outer-row oral teeth (e.g., [41, 128, 193, 194]); (iii) the riverine genus Haplochromis vanheusdeni at least partially displays cycloid scales on the flanks (see [195]), which is also known for species of Orthochromis and the Serranochromines (e.g., $[113,128,196])$.

+Warilochromis is very similar to the Haplochromini if the character combination of the tribe as a whole (i.e. including the above-mentioned exceptions) is considered. It shares the morphology of the caudal fin, scales, oral teeth (of piscivores) and pharyngeal teeth. In addition, its meristics and also the number of lateral-line tubules on the lacrimal fall within the range of the Haplochromini (see Fig. 7). A close affinity with the Haplochromini is additionally supported by the results of our multivariate analysis (Additional file 6: Supplementary Fig. S2), which places +Warilochromis near to the center of the 95\% ellipse of the Haplochromini. In contrast, there is only marginal overlap between +Warilochromis and the 95\% ellipses of the Tropheini, Perissodini, Cyprichromini and Lamprologini.

However, none of the lineages currently included in the Haplochromini displays exactly the same character set as is present in +Warilochromis (see Table 2). For example, a lacrimal with the lateral line divided into four tubules is known only in species of the riverine genus Pseudocrenilabrus [21, 127]. But, unlike †Warilochromis, species of Pseudocrenilabrus display weakly ctenoid scales below the anterior lateral-line segment [127] and 
Table 2 Character combination of the haplochromine lineages recognized in Schedel et al., [17] and the respective combination in tWarilochromis gen. nov

\begin{tabular}{llll}
\hline Taxon & $\begin{array}{l}\text { Four lateral-line tubules on the } \\
\text { lacrimal }\end{array}$ & $\begin{array}{l}\text { Exclusive unicuspid oral } \\
\text { dentition }\end{array}$ & $\begin{array}{l}\text { Cycloid scales on } \\
\text { flanks }\end{array}$ \\
\hline tWarilochromis gen. nov & + & + & + \\
Lake Malawi flock & - & $+/-$ & $+/-$ \\
Riverine + Modern Haplochromini & - & $+/-$ & $+/-$ \\
Tropheini & - & - & $+/-$ \\
Haplochromis vanheusdeni & - & - & $+/-$ \\
Astatoreochromis straeleni & - & $+/-$ & $+/-$ \\
Pseudocrenilabrus group (incl. Orthochromis, & + - & - & + \\
Pseudocrenilabrus) & - & + & $+/-$ \\
Orthochromis indermauri & - & - & - \\
Serranochromines & - & - & $+/-$ \\
Ctenochromis pectoralis & - & - & \\
Malagarasi Orthochromis & - & \\
\hline
\end{tabular}

Information on morphological characters for recent haplochromine lineages from $[12,13,21,41,88,102,113,116,119,123,127-129,131,148,170,171,188$, 193-216]. Abbreviations: +, present; -, absent

the outer row of their oral dentition is never exclusively unicuspid [127]. In addition, the total vertebral counts of Pseudocrenilabrus do not exceed 30 ([127] and this study), whereas + Warilochromis has 33.

Taking all this information together, the particular combination of morphological characters exhibited by †Warilochromis clearly separates it from all other cichlid lineages except the Haplochromini, even though none of its included sublineages actually displays this precise set of traits. Thus, we propose that +Warilochromis represents an extinct genus and species whose affinities align it with the Haplochromini. Moreover, the peculiar configuration of the lacrimal with four lateral-line tubules argues for a close relationship with Pseudocrenilabrus, although some differences in squamation, dentition and meristics are evident (see above). The morphological differences between + Warilochromis and Pseudocrenilabrus could perhaps be explained by the fact that the extant members of Pseudocrenilabrus are adapted to a life in riverine habitats, as they are distributed in streams from Sudan to Uganda and the Congo Basin (e.g., [217]). In contrast, †Warilochromis derives from lake sediments.

\section{Comparison of + Warilochromis with previously described cichlid fossils from Africa, Arabia and Europe}

We begin by comparing +Warilochromis with taxa for which the character states relating to oral dentition and/or number of lateral-line tubules on the lacrimal are known. Then we compare the new specimen with those fossils for which these characters are unknown. In each case, we indicate in the following how the listed taxon differs from + Warilochromis.
Taxa for which at least one of the characters 'oral dentition' and 'number of lateral-line tubules on the lacrimal' is known:

i. †Mahengechromis spp. Murray, 2000 [218]; middle Eocene (c. 46 MYA) of Tanzania: hooked (vs. conical) unicuspid oral teeth on the dentary; more dorsal fin spines (D XV vs. D XIV); fewer vertebrae (22-25 vs. 33)

ii. †Macfadyena dabanensis Van Couvering, 1982 [70]; Oligocene Upper Daban Series of Somalia: two supraneurals (vs. one); all hypural plates clearly separated from each other (vs. fused)

iii. + Rhodopotilapia gracialis Kirilova \& Georgiev, 2015 [219]; early Oligocene Bulgaria: two supraneurals (vs. one); 27 vertebrae $(12+15)$ vs. 33; D XIV,16 (vs. D XIV, 10); A III,11 (vs. A III, 9)

iv. +Palaeofulu kuluensis Van Couvering, 1982 [70]; lower to middle Miocene Kulu Fm (17-15 MYA) of Kenya: 'leaf-shaped' (vs. conical) unicuspid oral teeth; two supraneurals (vs. one); fewer vertebrae (25-29 vs. 33)

v. †Oreochromimos kabchorensis Penk et al., 2019 [76]; middle Miocene (12.5 MYA), site Kabchore, Ngorora Fm Member C: uni- and tricuspid oral teeth (vs. solely unicuspid); 28-30 vertebrae (vs. 33); hypural plates separated (vs. fused)

vi. +Sarotherodon martyni Van Couvering, 1982 [70]; middle Miocene (ca. 12 MYA), Kapkiamu Shales, Ngorora Fm Member C: few anterior tricuspid outer-row teeth (vs. solely unicuspid); 29 vertebrae (vs. 33); hypural plates separated (vs. fused)

vii. $†$ Rebekkachromis ngororus and $+R$. kiptalami Kevrekidis, Valtl \& Reichenbacher, 2019 [75]; 
uppermost middle to lowermost upper Miocene (ca. 11 MYA), site Rebekka, Ngorora Fm Member D: tricuspid (vs. unicuspid) oral teeth; two supraneurals (vs. one)

viii.†Tugenchromis pickfordi Altner, Schliewen, Penk \& Reichenbacher, 2017 [16]; upper Miocene (ca. 9-10 MYA), site Waril, Ngorora Fm Member E: Six lateral-line tubules (vs. four) on the lacrimal; fewer vertebrae (29 vs. 33 )

ix. Cichlidae indeterminate Van Couvering, 1982 [70]; upper Miocene Mpesida Beds (ca. 6.8 MYA): stout unequally tricuspid to conical unicuspid oral teeth (vs. solely unicuspid)

x. †Oreochromis lorenzoi Carnevale, Sorbini \& Landini, 2003 [220]; upper Miocene Gessoso-Solfifera Fm (ca. 6 MYA): bicuspid and tricuspid oral teeth (vs. solely unicuspid); more dorsal and anal fin spines (D XV vs. D XIV and A IV vs. A III); deep-bodied xi. cf. Pelmatochromis Van Couvering [70]; lower Miocene Lamitina beds (ca. 22 MYA) of Uganda: six lateral-line tubules (vs. four) on the lacrimal

xii. 'Cichlidae indeterminate' by Van Couvering [70]; lower Miocene Turkana Grits $(17.5 \pm 0.9-16.7 \pm$ 0.8 MYA), Kenya: recurved, weakly tricuspid to sometimes unicuspid teeth and stout, equally bicuspid teeth (vs. solely unicuspid)

xiii.'Cichlidae indeterminate Form A' by Van Couvering, [70]; lower to middle Miocene Kulu Fm (17-15 MYA) of Kenya: tricuspid outer and bicuspid inner oral teeth (vs. solely unicuspid)

xiv. 'Cichlidae indeterminate Form B' by Van Couvering [70]; lower to middle Miocene Kulu Fm (17-15 MYA) of Kenya: unequally bicuspid oral tooth (vs. solely unicuspid)

xv. 'Cichlidae indeterminate-Group A' by Van Couvering [70]; middle Miocene Kirimun Beds Kenya: unicuspid, bicuspid and tricuspid oral teeth (vs. solely unicuspid)

List of fossil African cichlid taxa for which the characters 'oral dentition' and 'number of lateral-line tubules on the lacrimal' are unknown:

i. cf. Tylochromis Otero et al. [221] and Murray [222]; middle Eocene (37-39 MYA) of Libya and the upper Eocene-lower Oligocene (35.1-33.8 MYA) of Egypt ([221, 222]): molariform pharyngeal teeth (vs. bicuspid)

ii. 'Cichlidae indeterminate Form B' by Van Couvering [70]; Oligocene Upper Daban Series of Somalia: dorsal fin with D? XI,13 (vs. D XIV,10); 22 scales in longitudinal line (vs. approx. 28); hypural plates separated (vs. fused) iii. 'Cichlidae indeterminate Form D' by Van Couvering [70]; Oligocene Upper Daban Series of Somalia: fewer vertebrae (24 vs. 33); D XIII,11 (vs. D XIV,10); A VI,12 (vs. A III,9)

iv. Unnamed fossil by Weiler [223]; OligoceneMiocene of Jordan: fewer vertebrae (23 vs. 33)

v. ?Heterochromis Lippitsch \& Micklich [224]; Lower Miocene sediments of the Baid Fm of SW Saudi Arabia: probably 2 supraneurals (vs. 1); D XIIIXIV,13+ (vs. D XIV,10); AIV-V (vs. A III)

vi. Second species (unnamed) of Lippitsch \& Micklich [224]; lower Miocene sediments of the Baid Fm of SW Saudi Arabia: scaly soft-rayed part of the dorsal fin (vs. scaleless)

vii. 'Cichlidae indeterminate-Group B' by Van Couvering [70]; middle Miocene Kirimun Beds Kenya: anal fin extending to origin of caudal fin skeleton (vs. not); caudal fin with five hypurals (vs. fused)

viii. Unnamed cichlids by Argyriou [225]; upper Miocene sediments (ca. 6.8 MYA) of the Sahabi Fm from Sahabi, Libya: anterior process of the anguloarticular broad (vs. slender), ventral process of this bone short and almost vertical to anterior one (vs. acute angle between anterior and ventral processes).

\section{Previously described fossils putatively assigned to the Haplochromini}

According to Van Couvering [70] and Lippitsch \& Micklich [224], six fossil taxa (not included in the lists above) can be putatively attributed to the Haplochromini because they share some important features with them. However, all but one exhibit characters that are not typical for the Haplochromini (see below).

i. 'Cichlidae indeterminate Form A', Van Couvering [70]; Oligocene Upper Daban Series of Somalia: These isolated bones were attributed to a single species closely related to the haplochromines, perhaps intermediate between Hemichromis and Haplochromis, based on the presence of weakly tricuspid pharyngeal teeth. However, tricuspid pharyngeal teeth are also known from species of Coptodon (e.g., [226]) and South American cichlids (e.g., [227, 228]), and also occur in other fish families/orders e.g., Cyprinidae [229]; Hemiramphidae [230]; Cyprinodontiformes [231]. In fact, the striking shape of these teeth closely resembles that of the pharyngeal teeth of piscivorous Haplochromini [232], Coptodon (tribe Coptodonini) [226, 233], and Cichlinae of the genera Geophagus [228] and Apistogramma [227]. In addition to pharyngeal teeth, Van Couvering [70] 
described granular cycloid scales, which could indicate a relationship to the Tropheini. However, without inspection of the original material, the assignment of these isolated bones remains uncertain.

ii. 'Cichlidae indeterminate Form C', Van Couvering [70]; Oligocene Upper Daban Series of Somalia: Van Couvering [70] tentatively places the two partially preserved articulated skeletons (probably counterparts) among the haplochromines, because of the presence of four anal fin spines and ctenoid scales. However, the author mentions that two supraneurals could be discerned, and this condition is not found in the Haplochromini (see Fig. 7). The character combination displayed by these fossils (ctenoid scales $+>3$ anal fin spines + two supraneurals) is otherwise known only among present-day South American Cichlinae (e.g., [79, 234, 235]) and any relationship with the haplotilapiines or Haplochromini can be excluded.

iii. †Kalyptochromis hamulodentis Van Couvering, 1982 [70]; lower to middle Miocene Kulu Fm (1715 MYA) of Kenya: Van Couvering indicates that this fossil species shares with the haplochromine genera Tropheus and Pseudotropheus the bicuspid oral dentition, polyacanthous median fins and a large number of vertebrae. But she tentatively placed it near the Etroplines and the Tilapiines because she also noted the presence of some plesiomorph characters such as (i) two supraneurals, (ii) seven or more branchiostegal rays, (iii) a long hyoid complex and (iv) a hyomandibula with a short body, short ventral process, and large anteroventral process. We consider a close relationship with the Etroplinae to be unlikely, because the latter possess tricuspid or unicuspid teeth (see [236]). Among the remaining cichlids the combination of two supraneurals, four anal fin spines and bicuspid oral dentition seen in †Kalyptochromis is only known among the Tilapiini and Oreochromini (see $[15,76]$ ). However, even an assignment to the Cichlidae is problematic, because cichlids (by definition) have no more than five branchiostegal rays.

iv. + Nderechromis cichloides Van Couvering, 1982 [70]; lower to middle Miocene Kulu Fm (17-15 MYA) of Kenya: Van Couvering putatively attributed this fossil species to the haplochromines because of the morphology of its pharyngeal apophysis and parasphenoid, and the presence of ctenoid scales. However, the combination of a Haplochromis-type pharyngeal apophysis and ctenoid scales is also known for the South American genus Cichla [237] as well as for members of the Ectodini, Eretmodini, and Lamprologini (e.g.,) [238-240]. Moreover, the outline of the parasphenoid is difficult to discern in the figures in Van Couvering's [70] paper.

According to her interpretation of a conical oral dentition that lacks inner teeth, this fossil could be related to the Ectodini, or Eretmodini (see [13]).

v. Third species (unnamed) of Lippitsch \& Micklich [224]; lower Miocene sediments of the Baid Fm of SW Saudi Arabia: Lippitsch and Micklich [224] putatively assigned two fossil specimens from the Baid Fm to the haplochromines based on their combination of (i) ctenoid scales; (ii) anal fin with (probably) four spines and at least 10 rays; (iii) probably separated hypural plates. In addition, in the first description of the material by Micklich and Roscher [241], the authors mentioned the presence of probably numerous (in several rows), small ( $<1$ $\mathrm{mm}$ ), slender, slightly recurved, oral teeth, of which some might have been unicuspid. Among the extant Haplochromini and Tropheini, only Tropheus, Astatoreochromis, Orthochromis torrenticola and O. machadoi possess so many anal fin spines (this study and $[12,13,94,113,126$, 199]). All of them have a mixture of uni-, bi-, and tricuspid dentition [12, 94, 113, 126, 198, 216], and a combination of ctenoid and cycloid body scales $[13,126,216]$. Thus, a phylogenetic relationship between this fossil and the Haplochromini seems possible.

vi. +Palaeochromis rouselleti and $+P$. darestei Sauvage, 1907 [242]; upper Miocene Seybouse Gypsiferous Marls (> 7 MYA) of Algeria: Based on its leafshaped unicuspid, unequally bicuspid or tricuspid oral, and hooked bicuspid pharyngeal teeth, Van Couvering [70] puts +Palaeochromis in an intermediate position between Pelmatochromis sensu lato (sensu Thys van den Audenaerde [243]) and Tilapia sensu stricto (=Tilapiini without Chilochromis, see [15]). She also noted that Pseudocrenilabrus and some generalized species of Haplochromis display similar oral and pharyngeal tooth morphology, but that +Palaeochromis differs from both genera in its cycloid rather than ctenoid scales. However, there is an inconsistency in the generic diagnosis of +Palaeochromis, because Van Couvering [70] states that the scales are cycloid or ctenoid in $\dagger P$. rousellet $i$, while in the generic diagnosis for + Palaeochromis she mentions only granular cycloid scales. In addition, the assumption that all species of Pseudocrenilabrus and Haplochromis have ctenoid scales is incorrect, because some members of both genera can display both ctenoid as well as 
cycloid body scales (e.g., [127, 187, 194, 196]). Leaf-shaped teeth are typical for scale-eating cichlids of the tribe Perissodini (e.g., [244]), but have not been described for Haplochromini (e.g., [196]).

In summary, of the previously described putative haplochromine fossil cichlids, only the 'third species (unnamed)' of Lippitsch \& Micklich [224] from the Lower Miocene sediments of the Baid Fm of SW Saudi Arabia can be reasonably attributed to the Haplochromini.

In addition, each of the taxa discussed above are clearly distinct from our fossil. +Warilochromis does not show the tricuspid pharyngeal teeth seen in 'Cichlidae indeterminate Form A'. The taxon 'Cichlidae indeterminate Form C' has a very different combination of characters (see above) from that seen in + Warilochromis. The same is true for †Kalyptochromis hamulodentis, which has bicuspid dentition, two supraneurals, seven or more branchiostegal rays, more dorsal and anal fin spines (D XVII vs. D XIV and A IV vs. A III), and fewer vertebrae (30 vs. 33). In addition, there is a clear difference between $+N d$ derechromis cichloides and + Warilochromis due to the presence in the former of ctenoid (vs. cycloid) scales and the lack of oral inner teeth (vs. present). The 'third species (unnamed)' of Lippitsch \& Micklich [224] differs from †Warilochromis in having ctenoid scales, probably four anal fin spines and probably separated hypural plates. Finally, +Palaeochromis rouselleti and $+P$. darestei are clearly different from †Warilochromis because of their distinctive dentition, as described above.

\section{Palaeoecology of +Warilochromis}

The new fossil taxon possesses fang-like caniniform teeth, which is a typical feature of predatory fish (e.g., [245]). The fact that only a single specimen of + Warilochromis was found among the material recovered from the Waril site further supports this interpretation, as predators are expected to occur at much lower levels than their prey (e.g., [246-248]).

Among African cichlids, predatory species are known from almost all tribes and lineages. The most detailed functional classification of predatory strategies has been proposed by Schmitz [249]. He divides them into three categories: ambush (sit-and-wait); ballistic capture (sitand-pursue); and pursuit hunters, which actively seek and chase their prey. This last type of hunting strategy requires a streamlined body shape adapted to rapid swimming, whereas the other two strategies do not (see [245]). Given its relatively compact body shape, + Warilochromis may have been either a sit-and-pursue or sitand-wait hunter.

The sit-and-pursue strategy is relatively common among extant cichlids, and has been described for Cichlasoma (e.g., [250]), Crenicichla (e.g., [251]), Hemichromis (e.g., [252]), many Lamprologini (e.g., [253, 254]), Perissodini (e.g., [255]) and Haplochromini (e.g., [253, 256, 257]). In contrast, among African cichlids, the sit-and-wait strategy is only known for the piscivorous genus Nimbochromis of the Lake Malawi Haplochromini. This fish lies on the bottom on its side, and looks like a dead fish, owing to its blotchy coloration [37, 258, 259]. As soon as a scavenger gets close enough, the predator engulfs it [37, 258-260]. This strategy is also known as thanatosis or death feigning [37]. It was recently described also for a South American cichlid [259].

The only previously described putative haplochromine fossil (=third species (unnamed) of Lippitsch \& Micklich, [224]) has unicuspid oral teeth according to the original description, but further differentiation was hampered by their poor preservation (see [241]). If its oral dentition was exclusively unicuspid, this lower Miocene species may also have had a predatory lifestyle.

\section{New insights into the evolutionary history of the Lake Tanganyika Radiation cichlids}

Here we have shown that +Warilochromis can be assigned to the Haplochromini (Fig. 7) and could be related to Pseudocrenilabrus (Table 2). Its age and the site of its discovery in the Central Kenya Rift, which forms part of the eastern branch of the East African Rift System and is thus quite remote from Lake Tanganyika (Fig. 8), make it particularly noteworthy for a better understanding of the evolutionary history of the Haplochromini.

Salzburger et al. [25] introduced the notion of a 'primary lacustrine radiation' to explain the peculiar branching pattern seen among the Lake Tanganyika cichlids, i.e. the occurrence of several lineages separated by short branch lengths in sequence-based phylogenetic trees, as also revealed by other studies [28, 263, 264]. This pattern could result from a shift in diversification rates owing to the advent of fully lacustrine conditions in Lake Tanganyika around 5-6 MYA [25]. Salzburger et al. [25] recognized two series of cladogenetic events. The first series probably happened during the 'protolakes' stage (see below) and involved six seeding lineages (the ancestors of Boulengerochromis, Trematocarini, Bathybatini, Lamprologini, Eretmodini and the C-lineage (sensu Clabaut et al., [261]; including the tribes Benthochromini, Cyprichromini, Cyphotilapiini, Ectodini, Haplochromini, Limnochromini and Perissodini). The second series likely represents the primary radiation that took place in the fully lacustrine habitat and involved the major diversifications of the Lamprologini and the C-lineage (sensu Clabaut et al., [261]).

It is generally is assumed that the basin of Lake Tanganyika formed 9-12 MYA (see [265]). This is based on 


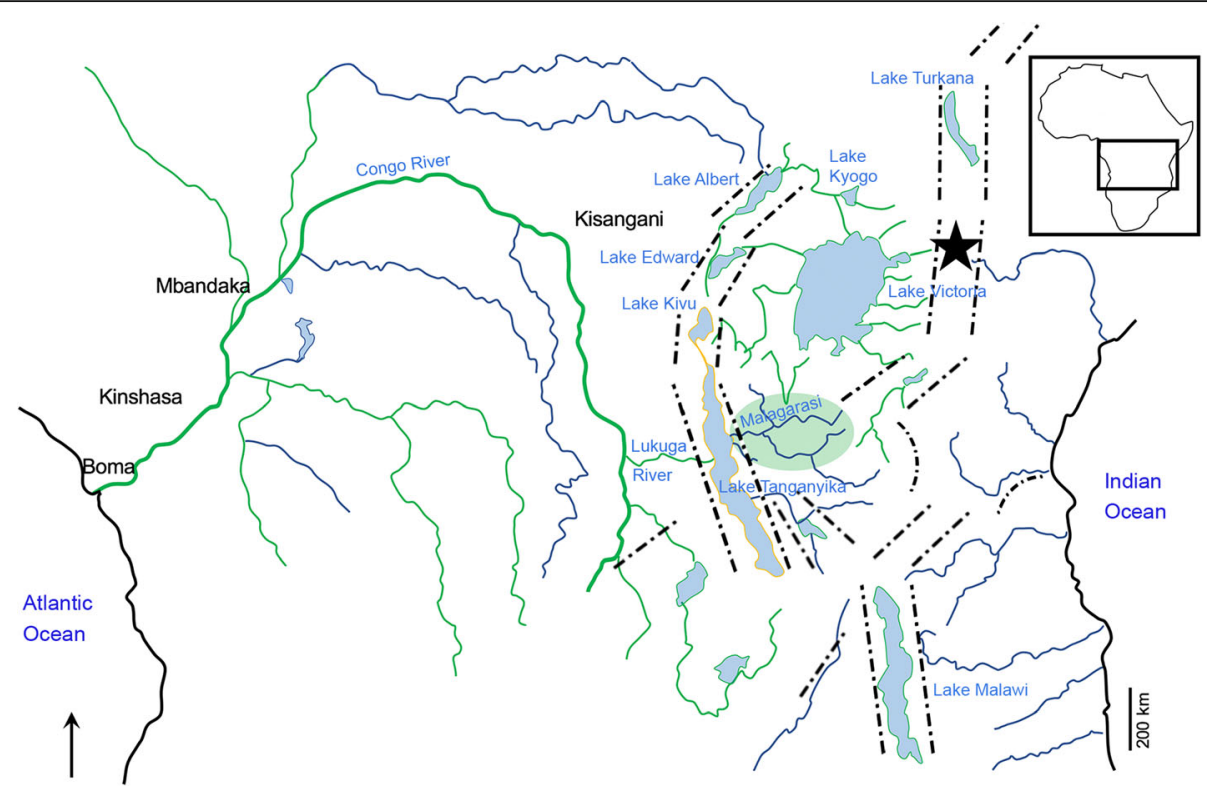

Fig. $8 \mathrm{Map}$ of East and Central Africa depicting the main present-day lakes and rivers, the tectonic structures of the Western and Eastern branches of the East African Rift System (dash-dotted lines) and the location of Palaeolake Waril (star), where the new fossil cichlid was found. The distribution of the present-day members of the Haplochromini in Lake Tanganyika (orange line), Lake Malawi and Victoria (green line), adjacent river systems and the Congo and Malagarasi Rivers is shown (green shading and lines). Source of map: River network drawn after Clabaut et al. [261] and Schwarzer et al. [262], distribution of haplochromine cichlids according to Schwarzer et al. [24]

the work of Cohen et al. [266] who, in the absence of stratigraphic data for deposits older than $35 \mathrm{ka}$ in the Lake Tanganyika Basin, used short-term sedimentation rates (derived from radiocarbon-dated core samples in Lake Tanganyika) and an approximate total sediment thickness for the Lake Tanganyika Basin (derived from reflection-seismic data) to calculate this age model. Moreover, a three-stage model of origin has been proposed for the Lake Tanganyika Basin by Tiercelin and Mondeguer [267]. These authors used significant signatures and changes in the seismic data and combined seismically derived sediment thicknesses in the Lake Tanganyika Basin with sedimentation rates drawn from the literature. Their three-stage model has been adopted and/or emended by subsequent authors (e.g., [265, 268]; see also $[25,269,270])$. According to the last group of authors, Stage 1 (20-14 MYA) was characterized by a weakly subsiding tectonic basin located in the western branch of the East African Rift System. It was drained by a wide, meandering stream and may have been connected to the Congo River drainage system. In Stage 2 (= 'protolakes' stage; 14-6 MYA), the development of tectonic half-grabens led to the progressive formation of several small, shallow $(<50 \mathrm{~m})$ and mostly isolated lakes. During Stage 3 (6-5 MYA), the half grabens were gradually connected into a large fault structure, and the isolated shallow lakes were progressively replaced by a single large lake, with deep-water conditions emerging at about 5 MYA. It seems plausible that this formation of deep-water lake conditions about 5 MYA gave rise to an adaptive radiation of the cichlid fishes in Lake Tanganyika, and therefore this age is commonly used as a calibration constraint (minimum age) in attempts to trace the course of the Lake Tanganyika Radiation of the cichlids (e.g., [271], and references therein).

Most publications use the age estimate proposed by Cohen et al. [266] for the formation of Lake Tanganyika of about 9-12 MYA. However, other estimates also exist, ranging from 14.5 to 5.5 MYA (see [272-274]). Previous studies focusing on molecular phylogenetics and divergence times of the Cichlidae use as calibration for the evolution of the Lake Tanganyika cichlids either the 9-12 million years (m.y.) age, or the 5-6 m.y. age for the emergence of deep lacustrine conditions within Lake Tanganyika [22, $275,276]$. Depending on the calibration point used, the nodes of the Haplochromini and Tropheini have highly variable ages, with ranges from 23 to 3 MYA and 11-2 MYA, respectively (see Table 3). Schedel et al. [17] calculated an age of nearly 12 MYA for the node of the whole Pseudocrenilabrus group. The finding of +Warilochromis, with an age of 9-10 MYA makes node ages for the Haplochromini younger than 9 MYA, as suggested by Koblmüller et al. [22], Friedman et al. [277], Meyer et al. [278] and Irisarri et al. [27] (see Table 3), unlikely. In addition, the age of the fossil also refutes the out of Tanganyika' hypothesis (sensu Salzburger et al., [45]) and 
Table 3 Summary of molecular studies dealing with the divergence times of cichlids with the respective calibration points used as well as the node age of the Haplochromini and Tropheini

\begin{tabular}{|c|c|c|c|}
\hline \multirow[t]{2}{*}{ Study/Reference } & \multirow[t]{2}{*}{ Calibration point } & \multicolumn{2}{|c|}{$\begin{array}{l}\text { Node age (MYA; mean, } \\
\text { SD or } 95 \% \text { confidence } \\
\text { interval or } 95 \% \text { HPD } \\
\text { interval or } 95 \% \text { credibility } \\
\text { interval) }\end{array}$} \\
\hline & & Haplochromini & Tropheini \\
\hline \multirow{2}{*}{$\begin{array}{l}\text { Genner et al., } \\
2007 \text { [11] }\end{array}$} & Gondwana; mitochondrial DNA only & $22.7 \pm 3.5$ & $6.8 \pm 1.1$ \\
\hline & Cichlid fossils; mitochondrial DNA only & $10.5 \pm 1.6$ & $3.0 \pm 0.5$ \\
\hline \multirow[t]{2}{*}{ Day et al., 2008 [275] } & Root of LTR set to 12 MYA & - & $\begin{array}{l}3.4, \\
2.7-4.5\end{array}$ \\
\hline & Root of LTR set to 28 MYA based on calibrations of Gondwana fragmentation & - & $\begin{array}{l}7.9, \\
6.3-10.5\end{array}$ \\
\hline $\begin{array}{l}\text { Koblmüller et al., } \\
2008 \text { [22] }\end{array}$ & $\begin{array}{l}\text { Lacustrine habitat in Lake Tanganyika (5-6 MYA) and Lake Malawi (0.57-1 MYA); Age of Lake } \\
\text { Victoria superflock (0.2 MYA) }\end{array}$ & $5.3,4.9-5.7$ & $\begin{array}{l}3.4, \\
3.0-4.0\end{array}$ \\
\hline $\begin{array}{l}\text { Santini et al., } \\
2009[279]\end{array}$ & 43 non-cichlid fossils; † Mahengechromis, Oligocene Heterochromis (23.3 MYA) & Ca. 9 & - \\
\hline $\begin{array}{l}\text { Friedman et al., } 2013 \\
\text { [277] }\end{array}$ & 10 non-cichlid fossils & Ca. 7 & $<5$ \\
\hline \multirow{2}{*}{$\begin{array}{l}\text { Meyer et al., } \\
2017 \text { [278] }\end{array}$} & Concatenation & - & - \\
\hline & Multispecies coalescent model & Ca. 5 & - \\
\hline \multirow[t]{11}{*}{ Irisarri, 2018 [27] } & Calibration scheme C10: & \multirow[t]{11}{*}{$6.9,3.3-10.5$} & \multirow{11}{*}{$\begin{array}{l}4.3, \\
1.9-6.7\end{array}$} \\
\hline & Gondwana fragmentation: & & \\
\hline & -Madagascar + India/Africa + South America max. 165 MYA & & \\
\hline & -Africa/ South America max. 101 MYA & & \\
\hline & - Madagascar/ India 88 MYA & & \\
\hline & - split Cichlasomatini/ Heroini 45.7-101 MYA & & \\
\hline & - Second split within African cichlids (excl. Heterochromis) 45.7-101 MYA & & \\
\hline & - Haplotilapiines (without Etiini) 9.3-62 MYA & & \\
\hline & - Oreochromini 5.98-47.5 MYA & & \\
\hline & - African cichlids 33.1-79.6 MYA & & \\
\hline & - H-lineage/ Lamprologini 9.3-43.2 MYA & & \\
\hline \multirow{8}{*}{$\begin{array}{l}\text { Schedel et al., } \\
2019[17]\end{array}$} & Calibration set 4: & \multirow[t]{8}{*}{$16.6,14.3-19.2$} & \multirow{8}{*}{$\begin{array}{l}\text { 8.7, } \\
6.8-10.7\end{array}$} \\
\hline & - †Tremembichthys 55.8-23.0 MYA & & \\
\hline & - †Gymnogeophagus eocenicus 45.4-39.9 MYA & & \\
\hline & - †Plesioheros chaulidus 45.4-39.9 MYA & & \\
\hline & - +Oreochromis lorenzoi 7.24-5.33 MYA & & \\
\hline & - †Tugenchromis pickfordi 9-10 MYA & & \\
\hline & - Onset Lake Barombi Mbo 1.12-0.98 MYA & & \\
\hline & - Estimated divergence age for family Cichlidae by Matschiner et al. (2016) 82.2-98.9 MYA & & \\
\hline
\end{tabular}

Abbreviations: HPD Highest posterior intervals, LTR Lake Tanganyika Radiation, MYA Million years ago, SD Standard deviation

the postulated date of 5-6 MYA for the onset of the divergence of the Haplochromini.

The only other fossil species that could reasonably represent a haplochromine, i.e. the third species (unnamed) of Lippitsch \& Micklich [224], derives from Lower Miocene sediments of the Baid Fm of SW Saudi Arabia. If its assignment to the Haplochromini can be confirmed in future work based on additional material, it would represent the oldest known fossil member of the Haplochromini. Furthermore, it would support the idea that the Haplochromini originated east of Lake Tanganyika, as proposed by Schedel et al. [17], as well as a scenario in which haplochromine cichlids were already present prior to the formation of Lake Tanganyika and colonized the lake only later. This would also confirm the conclusion of Altner et al. [16], based on 
†Tugenchromis pickfordi (which derives from the same locality as +Warilochromis), that ancient progenitors of the Lake Tanganyika Radiation were already present in the Miocene of the eastern branch of the East African Rift System (Fig. 8).

In addition, both + Warilochromis and + Tugenchromis support the hypothesis of a late Miocene hydrological connection between the Central Kenya Rift and Lake Tanganyika, and imply that ancient Lake Tanganyika cichlids were able to migrate through riverine waters during the late Miocene (Fig. 8). Such a hydrological network would be consistent with previous geological studies that proposed an ancient east-west hydrological connection between the Malagarasi and the Congo Rivers, which was probably disrupted by the rifting processes that led to the formation of Lake Tanganyika [265, 267, 280-282].

\section{Conclusion}

The fossil cichlid described here as + Warilochromis unicuspidatus gen. et sp. nov. represents an extinct genus and species of the Haplochromini, possibly related to the extant genus Pseudocrenilabrus. The age of the new fossil (9-10 MYA) implies that the Haplochromini must have emerged before this time and rules out the 'out of Tanganyika' hypothesis [45], i.e. the assumption that the divergence of the Haplochromini began only 5-6 MYA [25].

+Warilochromis was discovered at the site Waril in Central Kenya, in the eastern branch of the East African Rift. Both +Warilochromis and the putatively oldest fossil haplochromine from Saudi Arabia described earlier [224] are compatible with the suggestion, based on molecular data [17], that the Haplochromini first evolved east of Lake Tanganyika. Moreover, the remote location where +Warilochromis was found, together with the recent distribution of the Haplochromini, supports a hydrological connection between the Central Kenya Rift and the Lake Tanganyika drainage system, as suggested earlier in the context of the finding of the fossil cichlid †Tugenchromis pickfordi, a putative stem lineage of Lake Tanganyika cichlids [16].

With its fang-like oral dentition, †Warilochromis probably exhibited predatory, hunting behavior. In the absence of securely assigned haplochromine fossils with a similar type of teeth, +Warilochromis represents the first fossil predatory haplochromine. Furthermore, it indicates that this lifestyle had already evolved by 9 MYA, and that Haplochromini were already an important component of the East African drainage systems at that time.

\section{Methods}

\section{Fossil material}

One complete specimen preserved in lateral view (2014WA-16). The fossil specimen is currently housed at the
Department of Earth and Environmental Sciences, Ludwig-Maximilians University Munich, and will be deposited in Kipsaraman, Baringo County, Kenya, as soon as the new Baringo County Geopark has been established.

\section{Comparative material representing recent species}

The new fossil exhibits characters that can also be found in the Pelmatochromines, Hemichromines and Chromidotilapiines and in several tribes that contributed to the Lake Tanganyika Radiation. Consequently, the comparative dataset comprises all cichlid tribes and lineages of the Lake Tanganyika Radiation (see Fig. 1b) as compiled in Altner et al. [16], and newly assembled comparative data for the Pelmatochromines, Hemichromines and Chromidotilapiines (X-ray images of 42 species (14 genera, 94 individuals, see Additional file 1, Supplementary Data S1 and Additional file 2: Supplementary Data S2). For details concerning the degree of completeness of the dataset relating to the tribes and lineages of the Lake Tanganyika Radiation, see Altner et al. [16]: p. e1297819-5, and for similar information on the other datasets see Additional file 1: Supplementary Data S1.

\section{Fossil preparation, measurements, imaging}

Sediment particles covering the fossil were removed under a stereoscopic microscope (Leica M165 C) using a fine carbide needle mounted on the end of a mechanical pencil barrel. The specimen was investigated using both optical microscopy and X-ray micro-CT scanning. Micrographs were taken with a Leica M170 HD camera mounted on the same microscope and merged in Adobe Photoshop using the 'photomerge' option. Measurements were performed based on the merged microphotographs in ImageJ 1.49a [283] and recorded to the nearest 0.1 $\mathrm{mm}$. Measurements are shown in Additional file 3: Supplementary Fig. S1. All measurements were normalized with reference to the standard length. Graphical illustrations were prepared on the basis of the composite microphotographs.

The $\mathrm{x}$-ray images of recent specimens were assembled with a Faxitron UltraFocus digital X-ray cabinet.

The micro-CT scanning was performed on a Phoenix Nanotom m (GE Sensing \& Inspection Technologies $\mathrm{GmbH})$. The anterior and posterior parts of the fossil (with an overlapping area) were scanned separately. 1200 (anterior part) and 1280 (posterior part) projections (2.5 $\mathrm{s}$ each) were taken at a voltage of $120 \mathrm{kV}$ and a current of $130 \mathrm{~mA}$. The resulting 16 bit data sets (voxel sizes: 18 and $19.59 \mu \mathrm{m}$ ) were histogram adjusted and converted to 8 bit. The data sets were co-registered manually and merged using Amira 6.4 (FEI, Hillboro, OR, USA). The 
tool Volume Rendering of Amira was applied to examine the data.

\section{Morphological studies (fossil and comparative material)}

Abdominal vertebrae were identified by the absence of a closed haemal arch (according to Barel et al. [232]). Total vertebral counts include the terminal centrum (urostyle). In the dorsal and anal fins, every fin ray was counted regardless of whether it was supported by a pterygiophore or not. Interpretation of osteological characters follows Stiassny [85] and Takahashi [13, 88]. In total, the meristic counts cover nine characters, namely (i-iv) the numbers of all discernible dorsal and anal fin spines and rays, (v-vii) counts of abdominal, caudal and total vertebrae, (viii) the number of supraneural bones, and (ix) the ordinal number of the vertebra (counted anteriorly to posteriorly) that is associated with the pterygiophore of the last dorsal fin spine.

\section{Morphological character matrix}

A morphological data matrix that includes all African cichlid lineages is currently not available for a phylogenetic analysis. Here we use the morphological matrix of Stiassny [85] to tentatively place the new fossil within the Cichlidae (see [76] for same approach). Stiassny's [85] original matrix comprises 18 ingroup taxa and 28 characters (19 osteological; 8 soft tissue; 1 behavioral). We added her 'generalized percomorph taxon' as the outgroup (see [76] for details). We added the fossil taxon to the data matrix by inserting character states for four (of 28) characters (respective states given in brackets), i.e., numbers $8(0), 11(0), 25(1), 27(1)$; these characters refer to the suture between the vomerine wing and the parasphenoid, the total number of vertebrae, the number of supraneural bones and the number of tubules on the lacrimal (see Additional file 4: Supplementary Data S4 and Additional file 5: S5). The morphological matrix was edited in Mesquite 3.51 [284].

\section{Phylogenetic analysis}

Phylogenetic analyses of the morphological data matrix was performed under maximum parsimony in TNT 1.1 [285], using a combination of 'new technology' search options, i.e., parsimony ratchet, tree-drifting and treefusing. We used implied weighting $(K=12.0)$ according to Goloboff et al. [286]. In all other cases, the preset default settings were used. Clade support was assessed using standard bootstrapping (1000 replicates, absolute frequencies values). Following Hillis and Bull [287], clades with bootstrap values $\geq 70 \%$ were considered well supported. Phylogenetic trees were visualized and edited in FigTree 1.4.4 [288].

\section{Statistical analysis}

A principal coordinates analysis ( $\mathrm{PCoA}$ ) was run using PAST [289] version 3.18, in order to explore meristiccount variation between the new fossil taxon and the 16 modern pseudocrenilabrine tribes - in which the character combination single supraneural + exclusive unicuspid oral dentition (as seen in the fossil) can occur - on the basis of our comparative dataset (Additional file 2: Supplementary Data S2). The nine aforementioned meristic characters were used as variables.

\section{Supplementary information}

Supplementary information accompanies this paper at https://doi.org/10 1186/s12862-020-01602-x

Additional file 1. Supplementary Data S1. Comparative material of extant species used for X-ray analysis and assembly of meristic data.

Additional file 2. Supplementary Data S2. Meristic counts from x-rays.

Additional file 3. Supplementary Fig. S1. Morphometric measurements conducted for this study. A generalized cichlid fish depicting head-, body-, and fin-related linear measurements (re-drawn based on de Zeeuw et al., 2010 [114], Fig. 14 distributed under CC-BY license (https:// creativecommons.org/licenses/by/4.0/) with permission from Naturalis Biodiversity Center https://www.repository.naturalis.nl/record/358750). B1-2, Upper and lower jaw bones (right side, lateral view) of a haplochromine cichlid with measurements (modified from Van Oijen \& de Zeeuw, 2008] [194]: Figs. 3 \& 6., based on Haplochromis vonlinnei, distributed under CC-BY license (https://creativecommons.org/licenses/by/4.0/) with permission from Naturalis Biodiversity Center http://www.repository. naturalis.nl/record/261776). Abbreviations: art, angulo-articular; BL, body length; $\mathbf{h}$, minimal body height; dent, dentary; $\mathbf{H}$, maximal body height; $\mathbf{H 2}$, body height at origin of anal fin; HD, head depth; $\mathbf{H L}$, Head length; IA, length of anal fin base; lasc, length of premaxillary ascending process; IC, length of caudal fin; ID, length of dorsal fin base; ILj, length of lower jaw; Ipc, length of caudal peduncle; Ipmx, length of premaxilla; $\mathbf{I V}$, length of pelvic fin base; IVsp, length of pelvic fin spine; $\mathbf{p D}$, postdorsal distance; pmx , premaxilla; prA, preanal distance; prD, predorsal distance; $\mathbf{p r V}$, prepelvic distance; rart, retro-articular; $\mathbf{S L}$, standard length; TL, total length.

Additional file 4. Supplementary Data S4. Text file used for the phylogenetic analysis on the basis of the matrix of Stiassny [85].

Additional file 5. Character list and states used for phylogenetic analysis (compiled from Stiassny, [85]).

Additional file 6 Supplementary Fig. S2. Principal coordinates analysis (PCOA) scatter plot. Analysis based on eight meristic characters and the number of supraneurals from the 16 pseudocrenilabrine tribes (26 lineages) shown in Fig. 7 ( $N=854$; see Additional file 2: Supplementary Data S2 for raw data) and from +Warilochromis unicuspidatus gen. et sp. nov. Species score limits are visualized as 95\% confidence ellipses. Note that the ellipses shown encompass only members of the tribes that overlap with +Warilochromis. Coordinate 1 explains 47.13\% and Coordinate 2 explains $40.75 \%$ of the variation.

\section{Abbreviations}

\#LL: number of lateral-line segments on the body; \#Lt: number of lateral-line tubules on the lacrimal; \#Sn: number of supraneural bones; ach: anterior ceratohyal; art: angulo-articular; bh: basihyal; bp \& bp': basipterygium; cl \& cl': cleithrum; co: coracoid; dent: dentary; dhh: dorsal hypohyal; e: ectopterygoid; ep1, ep2: epurals; Fm: Formation; HPD: Highest posterior intervals; hs: haemal spines; hy1-5: hypural plates; hyo \& hyo': hyomandibula; Hyp 1-2, 3-4: configuration of the hypural plates; io1-4: infraorbitals 1-4; lac \& lac': lacrimal; LTR: Lake Tanganyika Radiation; m.y.: million years; MPT: Most parsimonious tree; mx: maxilla; MYA: Million years ago; ns: neural spines; o: otolith imprint; op: opercle; pa: palatine; pch: posterior ceratohyal; PCoA: Principal coordinates analysis; ph: parhypural; pmx \& pmx': premaxilla; 
pop: preopercle; psp: parasphenoid; ptt \& ptt': posttemporal; pu: preural centrum; s: symplectic; scl: supracleithrum; SD: Standard deviation; SL: Standard length; sn: supraneural; SNSB - BSPG: Bavarian State Collection of Palaeontology and Geology, Munich, Germany; SNSB - ZSM: Bavarian State Collection of Zoology, Munich, Germany; sop: suboperculum; un: uroneural; us: terminal centrum; v: vomer; vhh \& vhh': ventral hypohyal; Vt: total number of vertebrae; VtPtLDs: ordinal number (s) of vertebrae associated with the pterygiophore of the last dorsal fin spine; +: present; - : absent

\section{Acknowledgements}

The Research Authorisation (NCST/RCD/12B/012/54) was provided by the Kenyan National Council for Science and Technology (Nairobi). We are very grateful to W. Moturi, J.M. Mironga, and K.N.N. Ondimu (all of the Faculty of Environment \& Resources Development, Egerton University) for their essential scientific and logistical support. We thank M. Pickford (Musée National d'Histoire Naturelle, Paris, France) and the members of the Orrorin Community Organisation, who helped in all aspects of the fieldwork and provided support for our project. We are grateful to S. Sónyi (SNSB - BSPG)) for the preparation of the fish fossil in the field, and to $\mathrm{M}$. Schellenberger (SNSB - BSPG) for preparing the photograph shown in Fig. 2d. We thank $U$. Schliewen and F. Schedel (both SNSB-ZSM), C. Kevrekidis and S. Penk (Ludwig-Maximilians-Universität München, Germany) for insightful discussion. We are indebted to M. Dohrmann (Ludwig-Maximilians-Universität München, Germany) for valuable advice concerning the phylogenetic methods and interpretations. We are grateful to J. Maclaine (Natural History Museum, London, UK) and D. Neumann (SNSB-ZSM) who facilitated access to specimens of extant species, and we thank F. Schedel (SNSB-ZSM) for providing $X$-rays. We thank G. Wörheide and M. Reich, Director and Vice-Director of the SNSB - BSPG, Munich, for their kind support, and P. Hardy (Düsseldorf, Germany) for critical reading of the manuscript. Finally, we acknowledge funding for this work from the German Science Foundation by a grant to BRe (RE 1113/18-2).

\section{Authors' contributions}

MA and BRe studied the fossil specimen and drafted the manuscript. MA produced the Figures, Tables, Suppl. Data, Tables, generated the X-ray images and performed the PCoA and phylogenetic analyses. BRu produced the Micro-CT images. All authors reviewed and edited drafts of the manuscript. All authors approved the final manuscript.

\section{Funding}

Work on this project is funded by the German Research Foundation (Grant RE 1113/18-2). The funding body played no role in any aspect of the study itself, including its design, the sampling procedures employed, analysis and interpretation of the data and the writing of the manuscript.

\section{Availability of data and materials}

The datasets used and analysed during the current study are available in Additional file 1: Supplementary Data S1, Additional file 2: Supplementary Data S2 and Additional file 4: Supplementary Data S4.

\section{Ethics approval and consent to participate}

Not applicable.

\section{Consent for publication}

Not applicable.

\section{Competing interests}

The authors declare that they have no competing interests.

\section{Author details}

'Department of Earth and Environmental Sciences, Paleontology and Geobiology, Ludwig-Maximilians-Universität München, Richard-Wagner-Strasse 10, 80333 Munich, DE, Germany. ${ }^{2}$ Section Evertebrata Varia, SNSB - ZSM Bavarian State Collection of Zoology, Münchhausen-Strasse 21, 81247 Munich, DE, Germany. ${ }^{3}$ GeoBio-Center at Ludwig-Maximilians-Universität München, Richard-Wagner-Strasse 10, 80333 Munich, DE, Germany.
Received: 26 November 2019 Accepted: 6 March 2020

Published online: 05 June 2020

\section{References}

1. Nelson JS, Grande TC, Wilson MVH. Fishes of the world. 5th ed. Hoboken: Wiley: 2016.

2. Fricke R, Eschmeyer WN, Fong JD: Species by Family/Subfamily. http:// researcharchive.calacademy.org/research/ichthyology/catalog/ SpeciesByFamily.asp Electronic version accessed February 2019. 2019.

3. Salzburger W. Understanding explosive diversification through cichlid fish genomics. Nat Rev Genet. 2018;19:705-17.

4. Salzburger W, Meyer A. The species flocks of East African cichlid fishes: recent advances in molecular phylogenetics and population genetics. Naturwissenschaften. 2004;91(6):277-90.

5. Seehausen O. Hybridization and adaptive radiation. Trends Ecol Evol. 2004; 19(4):198-207.

6. Koblmüller S, Sefc KM, Sturmbauer C. The Lake Tanganyika cichlid species assemblage: recent advances in molecular phylogenetics. Hydrobiologia. 2008:615(1):5-20.

7. Muschick M, Barluenga M, Salzburger W, Meyer A. Adaptive phenotypic plasticity in the Midas cichlid fish pharyngeal jaw and its relevance in adaptive radiation. BMC Evol Biol. 2011;11(116):1-12.

8. Brawand D, Wagner CE, Li Yl, Malinsky M, Keller I, Fan S, Simakov O, Ng AY, Lim ZW, Bezault E, et al. The genomic substrate for adaptive radiation in African cichlid fish. Nature. 2014;513(7518):375-81.

9. Kocher TD. Adaptive evolution and explosive speciation: the cichlid fish model. Nat Rev Genet. 2004;5(4):288-98.

10. Seehausen $\mathrm{O}$. African cichlid fish: a model system in adaptive radiation research. Proc R Soc B Biol Sci. 2006;273(1597):1987-98.

11. Genner MJ, Seehausen O, Lunt DH, Joyce DA, Shaw PW, Carvalho GR, Turner GF. Age of cichlids: new dates for ancient lake fish radiations. Mol Biol Evol. 2007;24(5):1269-82.

12. Poll M. Classification des Cichlidae du lac Tanganika. Tribus, genres et espèces. Acad R Belg Mem Cl Sci. 1986;45(2):1-163.

13. Takahashi T. Systematics of Tanganyikan cichlid fishes (Teleostei: Perciformes). Ichthyol Res. 2003;50(4):367-82.

14. Schwarzer J, Misof B, Tautz D, Schliewen UK. The root of the East African cichlid radiations. BMC Evol Biol. 2009;9(186):1-11.

15. Dunz AR, Schliewen UK. Molecular phylogeny and revised classification of the haplotilapiine cichlid fishes formerly referred to as "Tilapia". Mol Phylogenet Evol. 2013;68(1):64-80.

16. Altner M, Schliewen UK, Penk SBR, Reichenbacher B. †Tugenchromis pickfordi, gen. et sp. nov., from the upper Miocene-a stem-group cichlid of the 'East African Radiation'. J Vertebr Paleontol. 2017;37(2):e1297819.

17. Schedel FDB, Musilová Z, Schliewen UK. East African cichlid lineages (Teleostei: Cichlidae) might be older than their ancient host lakes: new divergence estimates for the East African cichlid radiation. BMC Evol Biol. 2019;19(1):94.

18. De Vos L, Seegers L, Taverne L, Thys van den Audenaerde D. L'ichthyofaune du bassin de la Malagarasi (Système du Lac Tanganyika): une synthèse de la connaissance actuelle. Annalen Zoologische Wetenschappen. 2001;285:117-35.

19. Schelly R, Stiassny ML, Seegers L. Neolamprologus devosi sp. n., a new riverine lamprologine cichlid (Teleostei, Cichlidae) from the lower Malagarasi River, Tanzania. Zootaxa. 2003;373:1-11.

20. Schelly RC, Stiassny ML. Revision of the Congo River Lamprologus Schilthuis, 1891 (Teleostei: Cichlidae), with descriptions of two new species. Am Mus Novit. 2004;3451:1-40.

21. Oliver MK. Systematics of African cichlid fishes: determination of the most primitive taxon, and studies on the haplochromines of Lake Malawi (Teleostei: Cichlidae). New Haven: Yale University; 1984.

22. Koblmüller S, Schliewen UK, Duftner N, Sefc KM, Katongo C, Sturmbauer C. Age and spread of the haplochromine cichlid fishes in Africa. Mol Phylogenet Evol. 2008;49(1):153-69.

23. Hermann CM, Sefc KM, Koblmuller S. Ancient origin and recent divergence of a haplochromine cichlid lineage from isolated water bodies in the East African Rift System. J Fish Biol. 2011;79(5):1356-69.

24. Schwarzer J, Swartz ER, Vreven E, Snoeks J, Cotterill FP, Misof B, Schliewen UK. Repeated trans-watershed hybridization among haplochromine cichlids (Cichlidae) was triggered by Neogene landscape evolution. Proc R Soc B Biol Sci. 2012;279:4389-98. 
25. Salzburger W, Meyer A, Baric S, Verheyen E, Sturmbauer C. Phylogeny of the Lake Tanganyika cichlid species flock and its relationship to the Central and East African haplochromine cichlid fish faunas. Syst Biol. 2002;51(1):113-35.

26. Verheyen E, Salzburger W, Snoeks J, Meyer A. Origin of the superflock of cichlid fishes from Lake Victoria. East Africa Science. 2003;300(5617):325-9.

27. Irisarri I, Singh $P$, Koblmüller $S$, Torres-Dowdall J, Henning F, Franchini $P$, Fischer C, Lemmon AR, Moriarty Lemmon E, Thallinger GG, et al. Phylogenomics uncovers early hybridization and adaptive loci shaping the radiation of Lake Tanganyika cichlid fishes. Nat Commun. 2018;9(3159):1-12.

28. Sturmbauer C, Meyer A. Mitochondrial phylogeny of the endemic mouthbrooding lineages of cichlid fishes from Lake Tanganyika in eastern Africa. Mol Biol Evol. 1993;10(4):751-68.

29. Konings A. Malawi cichlids in their natural habitat. El Paso: Cichlid Press; 2001.

30. Wanek KA, Sturmbauer C. Form, function and phylogeny: comparative morphometrics of Lake Tanganyika's cichlid tribe Tropheini. Zool Scr. 2015; 44(4):362-73.

31. Tada S, Hori M, Yamaoka K, Hata H. Diversification of functional morphology in herbivorous cichlids (Perciformes: Cichlidae) of the tribe Tropheini in Lake Tanganyika. Hydrobiologia. 2017;791:83-101.

32. Hori M. Mutualism and commensalism in the fish community in Lake Tanganyika. In: Kawano S, Connell JH, Hidaka T, editors. Evolution and coadaptation in biotic communities. Tokyo: University of Tokyo Press; 1987. p. 219-39.

33. Yuma M. Food habits and foraging behaviour of benthivorous cichlid fishes in Lake Tanganyika. Environ Biol Fish. 1994;39:173-82.

34. Sturmbauer C, Hainz U, Verheyen E, Salzburger W. Evolution of the tribe Tropheini from Lake Tanganyika: synchronized explosive speciation producing multiple evolutionary parallelism. Hydrobiologia. 2003;500:51-64.

35. Fryer $\mathrm{G}$. The trophic interrelationships and ecology of some littoral communities of Lake Nyasa with especial reference to the fishes and a discussion of the evolution of a group of rock-frequenting Cichlidae. Proc Zool Soc London. 1959;132(2):153-281.

36. Greenwood PH. The cichlid fishes of Lake Victoria, East Africa: The biology and evolution of a species flock. Bull Br Mus (Nat Hist) Zool. 1974;6:3-134.

37. McKaye KR. Field observationon death feigning: a unique hunting behavior by the predatory cichlid, Haplochromis livingstoni, of Lake Malawi. Environ Biol Fish. 1981;6(3/4):361-5.

38. McKaye KR, Kocher T. Head ramming behaviour by three paedophagous cichlids in Lake Malawi. Africa Anim Behav. 1983;31(1):206-10.

39. Ribbink AJ. The feeding behaviour of a cleaner and scale, skin and fin eater from Lake Malawi (Docimodus evelynae; Pisces, Cichlidae). Neth J Zool. 1984; 34(2):182-96.

40. Stauffer JR, McKaye KR. Description of a paedophagous deep-water cichlid (Teleostei: Cichlidae) from Lake Malawi. Africa P Biol Soc Wash. 1986;99:29-33.

41. Van Oijen MJP. A systematic revision of the piscivorous haplochromine Cichlidae (Pisces: Teleostei) of Lake Victoria (East Africa). Part I. Zool Verh (Leiden). 1991;272(24):1-95.

42. Bouton N, Seehausen O, van Alphen JJM. Resource partitioning among rock-dwelling haplochromines (Pisces: Cichlidae) from Lake Victoria. Ecol Freshw Fish. 1997:6:225-40.

43. Salzburger W, Braasch I, Meyer A. Adaptive sequence evolution in a color gene involved in the formation of the characteristic egg-dummies of male haplochromine cichlid fishes. BMC Biol. 2007;5:51.

44. Muschick M, Indermaur A, Salzburger W. Convergent evolution within an adaptive radiation of cichlid fishes. Curr Biol. 2012;22:2362-8.

45. Salzburger W, Mack T, Verheyen E, Meyer A. Out of Tanganyika: genesis, explosive speciation, key-innovations and phylogeography of the haplochromine cichlid fishes. BMC Evol Biol. 2005;5:17.

46. Weiss JD, Cotterill FPD, Schliewen UK. Lake Tanganyika-a 'melting pot' of ancient and young cichlid lineages (Teleostei: Cichlidae)? PLoS One. 2015; 10(4):e0125043.

47. Le Gall B, Tiercelin JJ, Richert J-P, Gente P, Sturchio NC, Stead D, Le Turdu C. A morphotectonic study of an extensional fault zone in a magma-rich rift: the Baringo Trachyte Fault System, Central Kenya. Rift Tectonophysics. 2000; 320:87-106.

48. Hautot S, Tarits P, Whaler K, Le Gall B, Tiercelin J-J, Le Turdu C. Deep structure of the Baringo Rift Basin (Central Kenya) from three-dimensional magnetotelluric imaging: implications for rift evolution. J Geophys Res-Solid Earth. 2000;105(B10):23493-518.
49. Kingston JD, Fine Jacobs B, Hill A, Deino A. Stratigraphy, age and environments of the late Miocene Mpesida beds, Tugen Hills. Kenya J Hum Evol. 2002;42(1-2):95-116.

50. Owen RB, Renaut RW, Lowenstein TK. Spatial and temporal geochemical variability in lacustrine sedimentation in the East African Rift System: evidence from the Kenya Rift and regional analyses. Sedimentology. 2018; 65:1697-730.

51. Hill A, Drake R. Sedimentary stratigraphy of the Tugen Hills, Baringo, Kenya. Geol Soc Lond Spec Publ. 1986;25:285-95.

52. Hill A. Paleoanthropological research in the Tugen Hills, Kenya. J Hum Evol. 2002;42(1-2):1-10.

53. Bishop WW, Chapman GR. Early Pliocene sediments and fossils from the northern Kenya Rift Valley. Nature. 1970;226:914-8.

54. Bishop WW, Pickford MHL. Geology, fauna and palaeoenvironments of the Ngorora Formation Kenya Rift Valley. Nature. 1975;254:185-92.

55. Rasmussen C, Reichenbacher B, Lenz O, Altner M, Penk SBR, Prieto J, Brüsch D. Middle-late Miocene palaeoenvironments, palynological data and a fossil fish Lagerstätte from the Central Kenya Rift (East Africa). Geol Mag. 2017; 154(1):24-56.

56. Jacobs BF. Estimation of low-latitude paleoclimates using fossil angiosperm leaves: examples from the Miocene Tugen Hills, Kenya. Paleobiology. 2002; 28(3):399-421.

57. Jacobs $B F$, Pan $A D$, Scotese $C R$. A review of the Cenozoic vegetation history of Africa. In: Werdelin L, Sanders WJ, editors. Cenozoic mammals of Africa. Berkeley: University of California Press; 2010. p. 57-72.

58. Jacobs BF, Kabuye CHS. A middle Miocene (12.2 my old) forest in the East African Rift Valley, Kenya. J Hum Evol. 1987;16(2):147-55.

59. Kingston JD, Marino BD, Hill A. Isotopic evidence for Neogene hominid paleoenvironments in the Kenya Rift Valley. Science. 1994;264(5161):955-9.

60. Jacobs BF, Deino AL. Test of climate-leaf physiognomy regression models, their application to two Miocene floras from Kenya, and Ar-40/Ar-39 dating of the late Miocene Kapturo site. Palaeogeogr Palaeoclimatol Palaeoecol. 1996;123(1-4):259-71.

61. Jacobs BF. Estimation of rainfall variables from leaf characters in tropical Africa. Palaeogeogr Palaeoclimatol Palaeoecol. 1999;145:231-50.

62. Jacobs BF. Palaeobotanical studies from tropical Africa: relevance to the evolution of forest, woodland and savannah biomes. Philos T Roy Soc B. 2004;359(1450):1573-83.

63. Hill A. Causes of perceived faunal change in the later Neogene of East Africa. J Hum Evol. 1987;16:583-96.

64. Senut B, Pickford M, Gommery D, Mein P, Cheboi K, Coppens Y. First hominid from the Miocene (Lukeino Formation, Kenya). C R Acad Sci Paris Sciences de la Terre et des planètes. 2001;332:137-44.

65. Behrensmeyer AK, Deino AL, Hill A, Kingston JD, Saunders JJ. Geology and geochronology of the middle Miocene Kipsaramon site complex, Muruyur Beds, Tugen Hills, Kenya. J Hum Evol. 2002;42(1-2):11-38.

66. Winkler AJ. Neogene paleobiogeography and East African paleoenvironments: contributions from the Tugen Hills rodents and lagomorphs. J Hum Evol. 2002;42(1-2):237-56.

67. Pickford M, Senut B, Mourer-Chauviré U. Early Pliocene Tragulidae and peafowls in the Rift Valley, Kenya: evidence for rainforest in East Africa. Comptes Rendus Palevol. 2004;3(3):179-89.

68. Van Couvering JAH. Palaeontology and comparative osteology of some African cichlid fishes. Cambridge: University of Cambridge; 1972.

69. Van Couvering JAH. Early records of freshwater fishes in Africa. Copeia. 1977; 1977(1):163-6.

70. Van Couvering JAH. Fossil cichlid fish of Africa. Spec Pap Palaeontol. 1982; 29:1-103.

71. Pickford M. Late Miocene sediments and fossils from the northern Kenya Rift Valley. Nature. 1975;256:279-84.

72. Pickford MHL. Geology, palaeoenvironments and vertebrate faunas of the mid-Miocene Ngorora Formation, Kenya. Geol Soc Lond Spec Publ. 1978;6: 237-62.

73. Pickford MHL. Stratigraphy and mammalian paleontology of the lateMiocene Lukeino Formation, Kenya. Geol Soc Lond Spec Publ. 1978;6: 263-78.

74. Altner M, Reichenbacher B. TKenyaichthyidae fam. nov. and TKenyaichthys gen. nov. - First record of a fossil aplocheiloid killifish (Teleostei, Cyprinodontiformes). PLoS One. 2015;10(4):e0123056.

75. Kevrekidis C, Valtl M, Penk SBR, Altner M, Reichenbacher B. Rebekkachromis nov. gen. From the middle-upper Miocene (11 MYA) of Central Kenya: the 
oldest record of a haplotilapiine cichlid fish. Hydrobiologia. 2019;832(1):3964.

76. Penk SBR, Altner M, Cerwenka AF, Schliewen UK, Reichenbacher B. New fossil cichlid from the middle Miocene of East Africa revealed as oldest known member of the Oreochromini. Sci Rep. 2019;9(1):10198.

77. Pickford M, Senut B, Cheboi K. The geology and paleobiology of the Tugen Hills, Kenya. Geo-Pal Kenya. 2009;1:1-134.

78. Vandewalle P. Ostéologie caudale des Cichlidae (Pisces, Teleostei). Bull biol Fr Bel. 1973;107(4):275-89.

79. Cichocki FP. Cladistic history of cichlid fishes and reproductive strategies of the American genera Acarichthys, Biotodoma and Geophagus. (volumes I and II). Ann Arbor, Michigan: University of Michigan; 1976.

80. Fujita K. The caudal skeleton of teleostean fishes. Tokyo: Tokai University Press; 1990.

81. Webb JF. Ontogeny and phylogeny of the trunk lateral line system in cichlid fishes. J Zool. 1990;221:405-18.

82. Sebilia ASC, Andreata JV. Osteology of the caudal fin of some species of Cichlidae (Pisces, Perciformes, Labroidei). Revta bras Zool. 1991;7(3):307-18.

83. Carpenter KE, Niem VH. FAO species identification guide for fishery purposes. In: The living marine resources of the Western Central Pacific. Bony fishes part 3 (Menidae to Pomacentridae), vol. 5. Rome: FAO; 2001.

84. Takahashi T, Nakaya K. Description and familial allocation of the African fluvial genus Teleogramma to the Cichlidae. Ichthyol Res. 2002;49(2):171-80.

85. Stiassny MLJ. Phylogenetic intrarelationships of the family Cichlidae. In: Keenleyside MHA, editor. Cichlid fishes. London: Chapman \& Hall; 1991. p. $1-35$.

86. Kullander SO. A phylogeny and classification of the South American Cichlidae (Teleostei: Perciformes). In: Malabarba LR, Reis RE, Vari RP, Lucena ZM, CAS L, editors. Phylogeny and classification of neotropical fishes Part 5 Perciformes. Porto Alegre: Edipucrs; 1998. p. 461-98.

87. Greenwood PH. The genera of pelmatochromine fishes (Teleostei, Cichlidae). A phylogenetic review. Bull Br Mus (Nat Hist) Zool. 1987;53(3): 139-203.

88. Takahashi T. Comparative osteology of the infraorbitals in cichlid fishes (Osteichthyes: Teleostei: Perciformes) from Lake Tanganyika. Species Divers. 2003;8:1-26

89. Aibara M, Takahashi T, Nakaya K. Neolamprologus cancellatus, a new cichlid fish from Lake Tanganyika, Africa. Ichthyol Res. 2005;52:354-9.

90. Bailey RM, Stewart DJ. Cichlid fishes from Lake Tanganyika: additions to the Zambian fauna including two new species. Occas Pap Mus Zool Univ Mich. 1977;679:1-30

91. Bills IR, Ribbink AJ. Description of Lamprologus laparogramma sp. nov., and rediagnosis of Lamprologus signatus Poll 1956 and Lamprologus kungweensis Poll 1952, with notes on their ecology and behaviour (Teleostei: Cichlidae). S Afr J Sci. 1997;93:555-64.

92. Black KE. Taxonomic analysis of the Metriaclima zebra species complex in Lake Malawi with five new species descriptions. Pennsylvania: Pennsylvania State University The Graduate School College of agricultural Sciences; 2010.

93. Boulenger GA. Descriptions of new fishes from the upper Shiré River, British Central Africa, collected by Dr. Percy Rendall, and presented to the British museum by sir Harry H. Johnston, K. C. B. Proc Zool Soc London. 1897; 1896(4):915-20.

94. Boulenger GA. Report on the collection of fishes made by Mr. J. E. S. Moore in Lake Tanganyika during his expedition, 1895-96. Trans Zool Soc London. 1898;15:1-30

95. Boulenger GA. Report on the fishes recently obtained by Mr. J. E. S. Moore in Lake Tanganyika. Proc Zool Soc London. 1898;3:494-7.

96. Boulenger GA. Matériaux pour la faune du Congo. Ann Mus Congo Zool. 1899;1:1-164.

97. Boulenger GA. Second contribution to the ichthyology of Lake Tanganyika.-on the fishes obtained by the Congo Free State expedition under Lieut. Lemaire in 1898. Trans Zool Soc London. 1899:15(4):87-96.

98. Boulenger GA. Diagnoses of new fishes discovered by Mr. J. E. S. Moore in lakes Tanganyika and Kivu. Ann Mag Nat Hist. 1901;7:1-6.

99. Boulenger GA. Fourth contribution to the ichthyology of Lake Tanganyika.-report on the collection of fishes made by Dr. W. a. Cunnington during the third Tanganyika expedition, 1904-1905. Trans Zool Soc London. 1906;17(6): 537-601.

100. Boulenger GA. Mission Stappers au Tanganyika-Moero. Diagnoses de poissons nouveaux. I. Acanthoptérygiens, Opisthomes, Cyprinodontes. Rev Zool Afric. 1914;3:442-7.
101. Boulenger GA. On a collection of fishes from Lake Tanganyika, with descriptions of three new species. Proc Zool Soc London. 1919;1-4:17-20.

102. Bowers NJ, Stauffer J. J. R. new species of rock-dwelling cichlid (Pisces: Cichlidae) from Lake Malawii, Africa, with comments on Melanochromis vermivorus Trewavas. Copeia. 1993;1993(3):715-22.

103. Burgess WE. Julidochromis marksmithi, a new species of Julidochromis from the Tanzanian coast of Lake Tanganyika. Tanganika Magazyn. 2014;15:40-9.

104. Büscher HH. Ein neuer Tanganjika-Cichlide aus Zaire. Neolamprologus marunguensis n. sp. (Cichlidae, Lamprologini). DATZ. 1989:42:739-43.

105. Büscher HH. Xenotilapia papilio n. sp., ein neuer Cichlidae aus dem Tanganjikasee (Cichlidae, Ectodini). DATZ. 1990;43(5):289-93.

106. Büscher HH. Ein neuer Tanganjikasee-Cichlide aus Zaire. Neolamprologus pectoralis n. sp. (Cichlidae, Lamprologini). DATZ. 1991;44:788-92.

107. Büscher HH. Neue Schneckencichliden aus dem Tanganjikasee. Lamprologus meleagris n. sp. und L. speciosus n. sp. (Cichlidae, Lamprologini). DATZ. 1991; 44:374-82.

108. Büscher HH. Neolamprologus bifasciatus n. sp.: Ein neuer TanganjikaseeCichlide (Cichlidae, Lamprologini). DATZ. 1993;46:385-9.

109. Büscher HH. Ein neuer Cichlide aus dem Tanganjikasee. Neolamprologus ventralis n. sp. (Cichlidae, Lamprologini). DATZ. 1995;48:379-82.

110. Büscher HH. Ein neuer Cichlide von der zairischen Küste des Tanganjikasees. Neolamprologus variostigma n. sp. (Cichlidae, Lamprologini). DATZ. 1995;48: 794-7.

111. De Vos L, Nshombo M. Thys van den Audenaerde D. Trematocara zebra (Perciformes; Cichlidae), nouvelle espèce du Nord-Ouest du Lac Tanganyika (Zaire). Belg J Zool. 1996;126(1):3-20.

112. De Vos L, Risch L. Thys van den Audenaerde D. Xenotilapia nasus, nouvelle espece de poisson des zones sous-littorale et benthique du Nord du lac Tanganyika (Perciformes: Cichlidae). Ichthyol Explor Freshwaters. 1995;6(4): $377-84$.

113. De Vos L, Seegers L. Seven new Orthochromis species (Teleostei: Cichlidae) from the Malagarasi, Luiche and Rugufu basins (Lake Tanganyika drainage), with notes on their reproductive biology. Ichthyol Explor Freshwaters. 1998; 9(4):371-420.

114. de Zeeuw MP, Mietes M, Niemantsverdriet P, ter Huurne S, Witte F. Seven new species of detritivorous and phytoplanktivorous haplochromines from Lake Victoria. Zool Meded. 2010;84(9):201-50.

115. Gashagaza MM, Nakaya K, Sato T. Taxonomy of small-sized cichlid fishes in the shell-bed area of Lake Tanganyika. Jpn J Ichthyol. 1995;42(3/4):291-302.

116. Greenwood PH. A revision of the Lake Victoria Haplochromis species (Pisces, Cichlidae) Part I: H. obliquidens Hilgend., H. nigricans (Blgr.), H. nuchisquamulatus (Hilgend.) and H. lividus, sp. n. Bull Br Mus (Nat Hist) Zool. 1956:4(5):223-44.

117. Greenwood PH. The monotypic genera of cichlid fishes in Lake Victoria part II and III. Bull Br Mus (Nat Hist) Zool. 1959;5(7):163-218.

118. Greenwood PH. A revision of the Lake Victoria Haplochromis species (Pisces, Cichlidae) Pt. II. H. sauvagei (Pfeffer), H. prodromus Trewavas, H. granti Blgr., and H. xenognathus sp. n. Bull Br Mus (Nat Hist) Zool. 1957; 5(4):75-97.

119. Greenwood PH. The monotypic genera of cichlid fishes in Lake Victoria. Bull Br Mus (Nat Hist) Zool. 1956;3(7):295-333.

120. Greenwood PH. A revision of the Lake Victoria Haplochromis species (Pisces, Cichlidae) Part IV. Bull Br Mus (Nat Hist) Zool. 1960;6(4):227-81.

121. Greenwood PH. A revision of the Lake Victoria Haplochromis species (Pisces, Cichlidae) Part V. Bull Br Mus (Nat Hist) Zool. 1962;9(9):139-214.

122. Greenwood PH. A revision of the Lake Victoria Haplochromis species (Pisces, Cichlidae). Part VI. Bull Br Mus (Nat Hist) Zool. 1967;15(2):29-119.

123. Greenwood PH. A revision of the Haplochromis and related species (Pisces: Cichlidae) from Lake George, Uganda. Bull Br Mus (Nat Hist) Zool. 1973;25: 139-242.

124. Greenwood PH. Towards a phyletic classification of the 'genus' Haplochromis (Pisces, Cichlidae) and related taxa. Part I. Bull Br Mus (Nat Hist) Zool. 1979;35(4):265-322.

125. Greenwood PH. Towards a phyletic classification of the 'genus' Haplochromis (Pisces, Cichlidae) and related taxa. Part II; the species from lakes Victoria, Nabugabo, Edward, George and Kivu. Bull Br Mus (Nat Hist) Zool. 1980;39(1):1-101.

126. Greenwood PH. The haplochromine species (Teleostei, Cichlidae) of the Cunene and certain other Angolan rivers. Bull Br Mus (Nat Hist) Zool. 1984; 47(4):187-239. 
127. Greenwood PH. The taxonomic status and phylogenetic relationships of Pseudocrenilabrus fowler (Teleostei, Cichlidae). Ichthyol Bull J L B Smith Inst Ichthyol. 1989;54:1-16

128. Greenwood PH. A review of the serranochromine cichlid fish genera Pharyngochromis, Sargochromis, Serranochromis and Chetia (Teleostei: Labroidei). Bull nat Hist Mus Lond (Zool). 1993;59(1):33-44.

129. Greenwood PH, Gee JM. A revision of the Lake Victoria Haplochromis species (Pisces, cichlidae) part VII. Bull Br Mus (Nat Hist) Zool. 1969; 18(1):1-65.

130. Greenwood PH, Barel CDN. A revision of the Lake Victoria Haplochromis species (Pisces, Cichlidae), part VIII. Bull Br Mus (Nat Hist) Zool. 1978;33(2): 141-92.

131. Günther A. Second report on the reptiles, batrachians, and fishes transmitted by Mr. H. H. Johnston, C. B., from British Central Africa. Proc Zool Soc London. 1894;1893:616-28.

132. Hanssens M, Snoeks J. A new species and geographical variation in the Telmatochromis temporalis complex (Teleostei, Cichlidae) from Lake Tanganyika. J Fish Biol. 2003;63(3):593-616.

133. Hanssens M, Snoeks J. A morphometric revision of the genus Ophthalmotilapia (Teleostei, Cichlidae) from Lake Tanganyika (East Africa). Zool J Linnean Soc. 1999:125:487-512.

134. Hoogerhoud RJC, Witte F. Revision of species from the "Haplochromis" empodisma group - revision of the haplochromine species (Teleostei, Cichlidae) from Lake Victoria. Part II. Neth J Zool. 1981;31(1):232-74.

135. Katongo C, Seehausen O, Snoeks J. A new species of Pseudocrenilabrus (Perciformes: Cichlidae) from Lake Mweru in the upper Congo River system. Zootaxa. 2017;4237(1):181-90.

136. Konings AF, Stauffer JRJ. Review of the Lake Malawi genus Melanochromis (Teleostei: Cichlidae) with a description of a new species. Zootaxa. 2012; 3258:1-27.

137. Kullander SO, Karlsson M, Karlsson M. Lepidiolamprologus kamambae, a new species of cichlid fish (Teleostei: Cichlidae) from Lake Tanganyika. Zootaxa. 2012;3492:30-48

138. Kullander SO, Karlsson M, Karlsson M, Noren M. Chalinochromis cyanophleps, a new species of cichlid fish (Teleostei: Cichlidae) from Lake Tanganyika. Zootaxa. 2014;3790:425-38.

139. Kullander SO, Norén M, Karlsson M, Karlsson M. Description of Neolamprologus timidus, new species and review of $N$. furcifer from Lake Tanganyika (Teleostei: Cichlidae). Ichthyol Explor Freshwaters. 2014;24: 301-28.

140. Louisy P. Description de Telmatochromis brichardi (Pisces, Cichlidae, Lamprologini), espèce nouvelle du lac Tanganyika. Rev Fr Aquariol Herpetol. 1989;15:79-85

141. Matthes H. Un cichlide nouveau du lac Tanganika Julidochromis transcriptus. n. sp. Rev Zool Bot Afr. 1959;60(1-2):126-30.

142. Myers GS. Report on the fishes collected by H. C. Raven in Lake Tanganyika in 1920. Proc U S Natl Mus. 1936;84(2998):1-15.

143. Nakaya K, Gashagaza MM. Neolamprologus longicaudatus, a new cichlid fish from the Zairean coast of Lake Tanganyika. Jpn J Ichthyol. 1995; 42(1):39-43

144. Nichols JT. A few fishes from the southeast corner of the Congo basin. Am Mus Novit. 1928;309:1-4.

145. Nichols JT, LaMonte FR. A new Lamprologus from Lake Tanganyika. Am Mus Novit. 1931;478:1-2.

146. Oliver MK, Arnegard E. A new genus for Melanochromis labrosus, a problematic Lake Malawi cichlid with hypertrophied lips (Teleostei: Cichlidae). Ichthyol Explor Freshwaters. 2010;21(3):209-32.

147. Poll M. Cichlidae nouveaux du Lac Tanganika appartenant aux collections du Musée du Congo. Rev Zool Bot Afr. 1942;36(4):343-60.

148. Poll M. Descriptions de Poissons nouveaux du Lac Tanganika, appartenant aux familles des Clariidae et Cichlidae. Rev Zool Bot Afr. 1943;37(3-4):305-18.

149. Poll M. Descriptions de Cichlidae nouveaux recueillis par la mission hydrobiologique belge au Lac Tanganika (1946-1947). Bull Mus R Hist Nat Belg. 1948;24(26):1-31.

150. Poll M. Deuxième série de Cichlidae nouveaux recueillis par la mission hydrobiologique belge en Lac Tanganika (1946-1947). Bull Inst R Sci Nat Belg. 1949;25(33):1-55.

151. Poll M. Troisieme série de Cichlidae nouveaux recueillis par la mission hydrobiologique belge au lac Tanganika (1946-1947). Bull Inst R Sci Nat Belg. 1951;27(29):1-11.
152. Poll M. Quatrieme série de Cichlidae nouveaux recueillis par la mission hydrobiologique belge au lac Tanganika (1946-1947). Bull Inst R Sci Nat Belg. 1952;28(49):1-20

153. Poll M. Poissons Cichlidae. Résultats scientifiques. Exploration hydrobiologique du lac Tanganika (1946-1947). Bull Inst R Sci Nat Belg. 1956:3(5):1-619.

154. Poll M. Contribution a la faune ichthyologique du lac Tanganika, d'après les recoltes de P. Brichard Rev Zool Afr. 1974;88(1):99-110.

155. Poll M. Contribution à la connaissance du genre Lamprologus Schth. Description de quatre espèces nouvelles, réhabilitation de Lamprologus mondabu et synopsis remanié des espèces du lac Tanganika. Bull Cl Sci Acad R Belg 5E Ser. 1978;64(11):725-58.

156. Poll M. Contribution a la faune ichthyologique de lac Tanganyika. Révision du genre Limnochromis Regan, 1920. Description de trois genres nouveaux et d'une espèce nouvelle: Cyprichromis brieni. Ann Soc R Zool Belg. 1981; 111(1-4):163-79

157. Poll M. Description de Xenotilapia flavipinnis sp.n. du lac Tanganika (Pisces, Cichlidae). Rev Zool Afr. 1985;99(1):105-9.

158. Poll M, Stewart DJ. A new cichlid fish of the genus Xenotilapia from Lake Tanganyika, Zambia ( Pisces) Cichlidae. Rev Zool Afr. 1975;89(4):919-24.

159. Poll M, Stewart DJ. Un nouveau Lamprologus du sud du Lac Tanganika (Zambia) (Pisces, Cichlidae). Rev Zool Afric. 1977;91:1047-56.

160. Poll M. Thys van den Audenaerde D. Deux Cichlidae nouveaux du sud du Bassin du Congo. Rev Zool Bot Afr. 1965;72:322-33.

161. Roberts TR, Stewart DJ. An ecological and systematic survey of fishes in the rapids of the lower Zaïre or Congo River. Bull Mus Comp Zool. 1976;147(6): 239-317.

162. Schelly R, Takahashi T, Bills R, Hori M. The first case of aggressive mimicry among lamprologines in a new species of Lepidiolamprologus (Perciformes: Cichlidae) from Lake Tanganyika. Zootaxa. 1638;2007:39-49.

163. Schilthuis L. On a collection of fishes from the Congo; with description of some new species. Tijdschr Ned Dierk Ver. 1891;2(3):83-92.

164. Seegers L. Bemerkungen zur Gattung Pseudocrenilabrus. Teil 2: Pseudocrenilabrus multicolor victoriae nov. subsp. DATZ. 1990;43:99-103.

165. Seegers $L$. The fishes of the Lake Rukwa drainage. Annls Mus $r$ Congo Belge Ser 8vo Zool. 1996:278:1-407.

166. Skelton P. A complete guide to freshwater fishes of southern Africa. Cape Town: Struik Publishers; 2001

167. Staeck W. A new cichlid fish from Lake Tanganyika: Julidochromis dickfeldi sp. n. (Pisces, Cichlidae). Rev Zool Afr. 1975;89:981-6.

168. Staeck W. Lamprologus buescheri n. sp. from the Zambian part of Lake Tanganyika. Senckenberg Biol. 1983;63(5-6):325-8.

169. Staeck W, Seegers L. Neolamprologus cylindricus spec. nov. Beschreibung eines neuen Tanganjikacichliden aus dem südlichen Tansania und dem östlichen Sambia. DATZ. 1986;39:448-51.

170. Stauffer JR Jr, van Snik ES. New species of Petrotilapia (Teleostei: Cichlidae) from Lake Malaŵi. Africa Copeia. 1996:1996(3):695-702.

171. Stauffer JR Jr, Bowers NJ, Kellogg KA, McKaye KR. A revision of the blueblack Pseudotropheus zebra (Teleostei: Cichlidae) complex from Lake Malawi, Africa, with a description of a new genus and ten new species. Proc Acad Natl Sci Phila. 1997;148:189-230.

172. Steindachner F. Bericht über einige neue Fischarten aus dem Tanganyikasee. Anz Kaiserl Akad Wiss Math Naturwiss Kl. 1909;46(24):399_ 404.

173. Stiassny ML, Lamboj A, De Weirdt D, Teugels GG. 31. Cichlidae. In: ML S, Teugels GG, Hopkins CD, editors. The fresh and brackish water fishes of Lower Guinea, West-Central Africa Volume 2. Paris: IRD; 2007. p. 269-403.

174. Takahashi T. Systematics of the tribe Trematocarini (Perciformes: Cichlidae) from Lake Tanganyika. Africa Ichthyol Res. 2002;49:253-9.

175. Takahashi T. Phylogenetic analysis of Cyprichromini (Perciformes: Cichlidae) endemic to Lake Tanganyika and validation of the genus Paracyprichromis. Ichthyol Res. 2004;51:1-4.

176. Takahashi T, Hori M. Description of a new Lake Tanganyikan cichlid fish of the genus Cyprichromis (Perciformes: Cichlidae) with a note on sexual dimorphism. J Fish Biol. 2006;68:174-92

177. Takahashi T, Hori M, Nakaya K, Schaefer SA. New species of Cyprichromis (Perciformes: Cichlidae) from Lake Tanganyika. Africa Copeia. 2002;2002(4): 1029-36.

178. Takahashi T, Nakaya K. A taxonomic review of Xenotilapia sima and X. boulengeri (Cichlidae; Perciformes) from Lake Tanganyika. Ichthyol Res. 1997; 44(4):335-46. 
179. Takahashi T, Nakaya K. Callochromis stappersii (Boulenger, 1914) from Lake Tanganyika, a junior synonym of C. pleurospilus (Boulenger, 1906) (Perciformes, Cichlidae). Ichthyol Res. 1998;45:413-8.

180. Takahashi T, Yanagisawa Y, Nakaya K. Microdontochromis rotundiventralis, a new cichlid fish (Perciformes: Cichlidae) from Lake Tanganyika. Ichthyol Res. 1997:44(2):109-17.

181. Teugels GG. Thys van den Audenaerde DFE. The fresh and brackish water fishes of West Africa, vol. 2. Paris: Mus. Roy. Afr. Centr., Tervuren, Belgium and Editions de I'ORSTOM; 1992.

182. Tougas S, Stiassny ML. Lamprologus markerti, a new lamprologine cichlid (Teleostei: Cichlidae) endemic to the lower Congo River in the Democratic Republic of Congo, west-Central Africa. Zootaxa. 2014;3852: 391-400.

183. Trewavas E. XLIV. The cichlid fishes of Syria and Palestine. Ann Mag Nat Hist. 1942;9(55):526-36.

184. Trewavas E. Fishes of the crater lakes of the Northwestern Cameroons. Bonn Zool Beitr. 1962;1/3(13):146-92.

185. Trewavas E, Poll M. Three new species and two new subspecies of the genus Lamprologus, cichlid fishes of Lake Tanganyika. Bull Inst R Sci Nat Belg. 1952;28(50):1-16.

186. Verburg P, Bills R. Two new cichlid species of Neolamprologus (Teleostei: Cichlidae) from Lake Tanganyika, East Africa. Zootaxa. 2007;1612:25-44.

187. Weber M. Beiträge zur Kenntniss der Fauna von Süd-Afrika. Zool Jahrb Abt Anat Ontog Tiere. 1897;10(2):135-200.

188. Winemiller KO, Kelso-Winemiller LC. Serranochromis altus, a new species of piscivorous cichlid (Teleostei: Perciformes) from the upper Zambezi River. Copeia. 1991;1991(3):675-86.

189. Witte F, Witte-Maas ELM. Haplochromine cleaner fishes: a taxonomic and eco-morphological description of two new species - revision of the haplochromine species (Teleostei, Cichlidae) from Lake Victoria. Part I. Neth J Zool. 1981;31(1):203-31.

190. Stiassny ML. A phylogenetic overview of the lamprologine cichlids of Africa (Teleostei, Cichlidae): a morphological perspective. S Afr J Sci. 1997:93:513-23.

191. Liem KF. A phyletic study of the Lake Tanganyika cichlid genera Asprotilapia, Ectodus, Lestradea, Cunningtonia, Ophthalmochromis, and Ophthalmotilapia. Bull Mus Comp Zool. 1981;149:191-214.

192. Greenwood PH. The Ophthalmotilapia assemblage of cichlid fishes reconsidered. Bull Br Mus (Nat Hist) Zool. 1983;44(4):249-90.

193. Trewavas E. A revision of the genus Serranochromis Regan (Pisces, Cichlidae). Annls Mus r Congo Belge Ser 8vo Zool. 1964;125:1-58.

194. Van Oijen MJP, de Zeeuw MP. Haplochromis vonlinnei spec. nov., a piscivorous haplochromine cichlid (Teleostei, Perciformes) from the Mwanza Gulf area of Lake Victoria, Tanzania. Zool Meded. 2008;82(17):167-75.

195. Schedel FDB, Friel JP, Schliewen UK. Haplochromis vanheusdeni a new haplochromine cichlid species from the great Ruaha River drainage, Rufiji basin, Tanzania. Spixiana. 2014:37(1):135-49.

196. Schedel FDB, Vreven EJWMN, Manda BK, Abwe E, Manda AC, Schliewen UK. Description of five new rheophilic Orthochromis species (Teleostei: Cichlidae) from the upper Congo drainage in Zambia and the Democratic Republic of the Congo. Zootaxa. 2018;4461(3):301-49.

197. Pfeffer G. Ostafrikanische Fische gesammelt von Herrn Dr. F. Stuhlmann im Jahre 1888 und 1889. Jahrb Hamb wiss Anst. 1893;10(2):129-77.

198. Pellegrin J. Contribution a l'étude anatomique, biologique et taxinomique des poissons de la famille des Cichlidés. Mém Soc Zool Fr. 1903;16:41-399.

199. Regan CT. The cichlid fishes of Lake Nyassa. Proc Zool Soc London. 1922;1: 675-728.

200. Greenwood PH. LVII. On two species of cichlid fishes from the Malagarazi River (Tanganyika), with notes on the pharyngeal apophysis in species of the Haplochromis group. Ann Mag Nat Hist. 1954;7(78):401-14.

201. Greenwood PH. A revision and redescription of the monotypic cichlid genus Pharyngochromis (Teleostei, Labroidei). Bull Br Mus (Nat Hist) Zool. 1992:58(1):37-52.

202. Thys van den Audenaerde DFE. Les Haplochromis du Bas-Congo. Rev Zool Bot Afr. 1964;70(1-2):154-73.

203. Trewavas E. Nouvel examen des genres et sous-genres du complexe Pseudotropheus-Melanochromis du lac Malawi (Pisces, Perciformes, Cichlidae). Rev Fr Aquariol Herpetol. 1983;10(4):97-106.

204. Jubb RA. A new Serranochromis (Pisces, Cichlidae) from the Incomati River system, eastern Transvaal, South Africa. Ann Cape Prov Mus Nat Hist. 1967;6: $55-62$.
205. Jubb RA. A new Chetia (Pisces, Cichlidae) from the Incomati River system, eastern Transvaal, South Africa. Ann Cape Prov Mus Nat Hist. 1967;6:71-6.

206. Balon EK, Stewart DJ. Fish assemblages in a river with unusual gradient (Luongo, Africa - Zaire system), reflections on river zonation, and description of another new species. Environ Biol Fish. 1983;9(3/4):225-52.

207. McKaye KR, Stauffer JR. Description of a gold cichlid (Teleostei: Cichlidae) from Lake Malawi. Africa Copeia. 1986;1986(4):870-5.

208. Stauffer JR Jr, McKaye KR. Description of a genus and three deep water species of fishes (Teleostei: Cichlidae) from Lake Malawi. Africa Copeia. 1988, 1988(2):441-9.

209. Krupp F, Schneider W. The fishes of the Jordan River Drainage Basin and Azraq oasis. Fauna Saudi Arab. 1989;10:347-416.

210. Witte F, Van Oijen MJP. Taxonomy, ecology and fishery of Lake Victoria haplochromine trophic groups. Zool Verh (Leiden). 1990;262(15):1-47.

211. Kuusipalo L. Scale morphology in Malawian cichlids. J Fish Biol. 1998;52: 771-81.

212. Seehausen O, Lippitsch E, Bouton N, Zwennes H. Mbipi, the rock-dwelling cichlids of Lake Victoria: description of the three new genera and fifteen new species. Ichthyol Explor Freshwaters. 1998;9(2):129-228.

213. Bills Rl, Weyl OLF. A new species of the genus Chetia (Teleostei: Cichlidae) from the Lecitu River, Buzi system. Mozambique Smithiana Spec Publ. 2002; 1:1-13.

214. Genner MJ, Turner GF. The mbuna cichlids of Lake Malawi: a model for rapid speciation and adaptive radiation. Fish Fish. 2005;6:1-34.

215. Tawil P. Description of a new cichlid species from Lake Malawi, with reexamination of Cynotilapia afra (Günther, 1893) and Microchromis zebroides Johnson, 1975. Cybium. 2011;35(3):201-11.

216. Banyankimbona G, Vreven E, Snoeks J. A revision of the genus Astatoreochromis (Teleostei, Cichlidae). East Africa Eur J Taxon. 2013:39:1-21.

217. Daget J, Gosse J-P, Teugels GG. Thys van den Audenaerde DFE (eds.): checklist of the freshwater fishes of Africa volume IV. Bruxelles, Tervuren, Paris: ISNB, MRAC, ORSTOM; 1991.

218. Murray AM. Eocene cichlid fishes from Tanzania, East Africa. J Vertebr Paleontol. 2000;20(4):651-64.

219. Kirilova L, Georgiev V. Rhodopotilapia gracialis - new fossil genus and species of family Cichlidae. Early Oligocene, eastern Rhodopes, Bulgaria. C R Acad Bulg Sci. 2015;68(11):1413-8.

220. Carnevale G, Sorbini C, Landini W. Oreochromis Lorenzoi, a new species of tilapiine cichlid from the Late Miocene of Central Italy. J Vertebr Paleontol. 2003:23(3):508-16.

221. Otero O, Pinton A, Cappetta H, Adnet S, Valentin X, Salem M, Jaeger J-J. A fish assemblage from the middle Eocene from Libya (Dur at-Talah) and the earliest record of modern African fish genera. PLoS One. 2015;10(12): e0144358.

222. Murray AM. Lower pharyngeal jaw of a cichlid fish (Actinopterygii; Labroidei) from an early Oligocene site in the Fayum. Egypt J Vertebr Paleontol. 2002:22(2):453-5.

223. Weiler W. Fischfunde aus dem Tertiär des Wadi Araba-Grabens in Jordanien Geol Jb. 1970:89:193-208.

224. Lippitsch E, Micklich N. Cichlid fish biodiversity in an Oligocene lake. Ital J Zool. 1998:65(sup1):185-8.

225. Argyriou T. Description, paleoenvironmental and paleobiogeographical implications of Miocene fish faunas from Jabal Zaltan and Sahabi (Libya). Edmonton, Alberta: University of Alberta; 2014

226. Dunz AR, Schliewen UK. Description of a Tilapia (Coptodon) species flock of Lake Ejagham (Cameroon), including a redescription of Tilapia deckerti Thys van den Audenaerde, 1967. Spixiana. 2010;33(2):251-80.

227. Kullander SO. Cichlid fishes from the La Plata basin. Part IV. Review of the Apistogramma species, with description of a new species (Teleostei, Cichlidae). Zool Scr. 1982;11(4):307-13.

228. Gosse J-P. Révision du genre Geophagus (Pisces Cichlidae). Acad R Sci Outre-Mer Mem CI Sci Nat Med. 1975;19(3):1-172.

229. Roberts TR. Danionella translucida, a new genus and speciesof cyprinid fish from Burma, one of the smallest living vertebrates. Environ Biol Fish. 1986; 16(4):231-41.

230. Tibbetts IR, Carseldine L. Anatomy of a hemiramphid pharyngeal mill with reference to Arrhamphus sclerolepis krefftii (Steindachner) (Teleostei: Hemiramphidae). J Morphol. 2003;255:228-43.

231. Braganca PHN, Amorim PF, Costa WJEM. Pantanodontidae (Teleostei, Cyprinodontiformes), the sister group to all other cyprinodontoid killifishes as inferred by molecular data. Zoosystematics Evol. 2018;94(1):137-45. 
232. Barel CDN, Van Oijen MJP, Witte F, Witte-Maas ELM. An introduction to the taxonomy and morphology of the haplochromine Cichlidae from Lake Victoria - a manual to Greenwood's revision papers. Neth J Zool. 1977;27(4): 333-89.

233. Thys van den Audenaerde DFE. Les tilapia (Pisces, Cichlidae) du SudCameroun et du Gabon - Étude systématique. Annls Mus r Congo Belge Ser 8vo Zool. 1966;153:1-83.

234. Rican O, Kullander SO. The Australoheros (Teleostei: Cichlidae) species of the Uruguay and Paraná River drainages. Zootaxa. 1724;2008:1-51.

235. Ottoni FP. Australoheros sanguineus sp. n. - a new cichlid species from the rio Cubatão basin, southern Brazil (Cichlidae: Heroini). Vertebr Zool. 2013; 63(2):161-9.

236. Sparks JS. Phylogeny of the cichlid subfamily Etroplinae and taxonomic revision of the Malagasy cichlid genus Paretroplus (Teleostei: Cichlidae). Bull Am Mus Nat Hist. 2008;314(1):1-151.

237. Stiassny MLJ. The relationships of the neotropical genus Cichla (Perciformes, Cichlidae): a phyletic analysis including some functional considerations. J Zool. 1982;197(3):427-53.

238. Greenwood PH. A review of the pharyngeal apophysis and its significance in the classification of Asian cichlid fishes. Bull Br Mus (Nat Hist) Zool. 1978; 33:297-323.

239. Trewavas E. The pharyngeal apophysis on the base of the skull in cichlid fishes. Neth J Zool. 1985;35(4):716-9.

240. Takahashi T. Systematics of Xenotilapia Boulenger, 1899 (perciformes: Cichlidae) from Lake Tanganyika, Africa. Ichthyol Res. 2003;50:36-47.

241. Micklich N, Roscher B. Neue Fischfunde aus der Baid-Formation (Oligozän; Tihamat Asir, SW Saudi-Arabien). Neues Jahrb Geol Palaeontol Abh. 1990; 180(2):139-75.

242. Sauvage HE. Sur des Poissons de la famille des Cichlidés trouvés dans le terrain tertiaire de Guelma. C r hebd séances Acad sci. 1907;165(5):360-1.

243. Thys van den Audenaerde DFE. A preliminary contribution to a systematic revision of the genus Pelmatochromis HUBRECHT sensu lato (Pisces, Cichlidae). Rev Zool Bot Afr. 1968;77(3-4):372-91.

244. Takahashi R, Watanabe K, Nishida M, Hori M. Evolution of feeding specialization in Tanganyikan scale-eating cichlids: a molecular phylogenetic approach. BMC Evol Biol. 2007;7:195

245. Helfman GS, Collette BB, Facey DE, Bowen BW. The diversity of fishes: biology, evolution, and ecology. 2nd ed. Oxford: Wiley-Blackwell; 2009.

246. Ursin E. On the prey size preference of cod and dab. Medd Dan Fisk Havunders N S. 1973;7:85-98.

247. Stewart BD, Jones GP. Associations between the abundance of piscivorous fishes and their prey on coral reefs: implications for prey-fish mortality. Mar Biol. 2001;138:383-97.

248. Donald DB, Anderson RS. Resistance of the prey-to-predator ratio to environmental gradients and to biomanipulations. Ecology. 2003;84(9):2387-94.

249. Schmitz O. Predator and prey functional traits: understanding the adaptive machinery driving predator-prey interactions. F1000 Faculty Rev. 2017;6:1767.

250. Lezama E, Günther J. The routine metabolism of the guapote, Cichlasoma managuense (Gunther 1869), related to body weight and temperature. J Fish Biol. 1992:41:373-80.

251. Pocklington R, Dill LM. Predation on females or males: who pays for bright male traits? Anim Behav. 1995;49(4):1122-4.

252. Godin J-GJ, Smith SA. A fitness cost of foraging in the guppy. Nature. 1988; 333:69-71.

253. Liem KF. Modulatory multiplicity in the functional repertoire of the feeding mechanism in cichlid fishes. J Morphol. 1978;158:323-60.

254. Fischer S, Oberhummer E, Cunha-Saraiva F, Gerber N, Taborsky B. Smell or vision? The use of different sensory modalities in predator discrimination. Behav Ecol Sociobiol. 2017:71:143.

255. Kovac R, Boileau N, Muschick M, Salzburger W. The diverse prey spectrum of the Tanganyikan scale-eater Perissodus microlepis (Boulenger, 1898). Hydrobiologia. 2019;832:85-92.

256. Liem KF. Adaptive significance of intra- and interspecific differences in the feeding repertoires of cichlid fishes. Am Zool. 1980;20(1):295-314

257. Ribbink AJ. Alternative life-history styles of some African cichlid fishes. Environ Biol Fish. 1990;28:87-100.

258. Fryer G, lles TD. The cichlid fishes of the Great Lakes of Africa: their biology and evolution. Edinburgh: Oliver \& Boyd; 1972.

259. Tobler M. Feigning death in the central American cichlid Parachromis friedrichsthalii. J Fish Biol. 2005;66:877-81.
260. Humphreys RK, Ruxton GD. A review of thanatosis (death feigning) as an anti-predator behaviour. Behav Ecol Sociobiol. 2018;72:22

261. Clabaut C, Salzburger W, Meyer A. Comparative phylogenetic analyses of the adaptive radiation of Lake Tanganyika cichlid fish: nuclear sequences are less homoplasious but also less informative than mitochondrial DNA. J Mol Evol. 2005;61(5):666-81.

262. Schwarzer J, Misof B, Ifuta SN, Schliewen UK. Time and origin of cichlid colonization of the lower Congo rapids. PLoS One. 2011;6(7):e22380.

263. Nishida M. Lake Tanganyika as an evolutionary reservoir of old lineages of East African cichfid fishes: inferences from allozyme data. Experientia. 1991; 47(9):974-9.

264. Kocher TD, Conroy JA, McKaye KR, Stauffer JR, Lockwood SF. Evolution of $\mathrm{NADH}$ dehydrogenase subunit 2 in East African cichlid fish. Mol Phylogenet Evol. 1995;4(4):420-32.

265. Cohen AS, Lezzar K-E, Tiercelin J-J, Soreghan M. New palaeogeographic and lake-level reconstructions of Lake Tanganyika: implications for tectonic, climatic and biological evolution in a rift lake. Basin Res. 1997;9:107-32.

266. Cohen AS, Soreghan MJ, Scholz CA. Estimating the age of formation of lakes: an example from Lake Tanganyika, East African Rift System. Geol. 1993;21:511-4.

267. Tiercelin J, Mondeguer A. The geology of the Tanganyika Trough. In: Coulter G, editor. Lake Tanganyika and its life. New York: Natural History Museum; 1991. p. 7-48.

268. Lezzar K-E, Tiercelin J-J, De Batist M, Cohen AS, Bandora T, Van Rensbergen P, Le Turdu C, Mifundu W, Klerkx J. New seismic stratigraphy and Late Tertiary history of the North Tanganyika Basin, East African Rift System deduced from multichannel and high-resolution reflection seismic data and piston core evidence. Basin Res. 1996;8:1-28.

269. Sturmbauer C, Verheyen E, Meyer A. Mitochondrial phylogeny of the Lamprologini, the major substrate spawning lineage of cichlid fishes from Lake Tanganyika in eastern Africa. Mol Biol Evol. 1994;11(4):691-703.

270. Sturmbauer C. Explosive speciation in cichlid fishes of the African Great Lakes: a dynamic model of adaptive radiation. J Fish Biol. 1998;53:18-36.

271. Sturmbauer C, Salzburger W, Duftner N, Schelly R, Koblmüller S. Evolutionary history of the Lake Tanganyika cichlid tribe Lamprologini (Teleostei: Perciformes) derived from mitochondrial and nuclear DNA data. Mol Phylogenet Evol. 2010;57:266-84.

272. Spiegel C, Kohn BP, Belton DX, Gleadow AJW. Morphotectonic evolution of the Central Kenya rift flanks: implications for late Cenozoic environmental change in East Africa. Geol. 2007;35(5):427-30.

273. Bauer FU, Glasmacher UA, Ring U, Schumann A, Nagudi B. Thermal and exhumation history of the central Rwenzori Mountains, Western rift of the East African Rift System. Uganda Int J Earth Sci. 2010;99(7):1575-97.

274. Roller S, Hornung J, Hinderer M, Ssemmanda I. Middle Miocene to Pleistocene sedimentary record of rift evolution in the southern Albert Rift (Uganda). Int J Earth Sci. 2010;99:1643-61.

275. Day JJ, Cotton JA, Barraclough TG. Tempo and mode of diversification of Lake Tanganyika cichlid fishes. PLoS One. 2008;3(3):e1730.

276. Matschiner M. Gondwanan vicariance or trans-Atlantic dispersal of cichlid fishes: a review of the molecular evidence. Hydrobiologia. 2019;832(1):9-37.

277. Friedman M, Keck BP, Dornburg A, Eytan RI, Martin CH, Hulsey CD, Wainwright PC, Near TJ. Molecular and fossil evidence place the origin of cichlid fishes long after Gondwanan rifting. Proc R Soc B Biol Sci. 2013; 280(1770):20131733

278. Meyer BS, Matschiner M, Salzburger W. Disentangling incomplete lineage sorting and introgression to refine species-tree estimates for Lake Tanganyika cichlid fishes. Syst Biol. 2017;66(4):531-50.

279. Santini F, Harmon LJ, Carnevale G, Alfaro ME. Did genome duplication drive the origin of teleosts? A comparative study of diversification in ray-finned fishes. BMC Evol Biol. 2009;9(1):194.

280. Lévêque C. Biodiversity dynamics and conservation: the freshwater fish of tropical Africa. Cambridge: Cambridge University Press; 1997.

281. Goodier SA, Cotterill FP, O'Ryan C, Skelton PH, de Wit MJ. Cryptic diversity of African tigerfish (genus Hydrocynus) reveals palaeogeographic signatures of linked Neogene geotectonic events. PLoS One. 2011;6(12):e28775.

282. Flügel TJ, Eckardt FD, Cotterill FPD. The Present Day Drainage Patterns of the Congo River System and their Neogene Evolution. In: de Wit MJ, Guillocheau F, de Wit MCJ, editors. Geology and Resource Potential of the Congo Basin. Berlin Heidelberg: Springer; 2015. p. 315-37.

283. Rasband WS: ImageJ. In., 1.49v edn. Bethesda, Maryland, U.S.A.: U.S. National Institutes of Health; 1997-2016. https://imagej.nih.gov.ij/. 
284. Maddison WP, Maddison DR: Mesquite: a modular system for evolutionary analysis. Version 3.51 In., 3.51 edn; http://mesquiteproject.org . 2018.

285. Goloboff PA, Farris JS, Nixon KC. TNT, a free program for phylogenetic analysis. Cladistics. 2008;24(5):774-86.

286. Goloboff PA, Torres A, Arias JS. Weighted parsimony outperforms other methods of phylogenetic inference under models appropriate for morphology. Cladistics. 2018;34:407-37.

287. Hillis DM, Bull J. An empirical test of bootstrapping as a method for assessing confidence in phylogenetic analysis. Syst Biol. 1993;42(2):182-92.

288. Rambaut A. FigTree. Tree figure drawing tool version 1.4.4. Edinburgh: University of Edinburgh; 2018. http://tree.bio.ed.ac.uk/software/figtree/

289. Hammer $\varnothing$, Harper DAT, Ryan PD. PAST: paleontological statistics software package for education and data analysis. Palaeontol Electron. 2001;4(1):1-9.

\section{Publisher's Note}

Springer Nature remains neutral with regard to jurisdictional claims in published maps and institutional affiliations.

Ready to submit your research? Choose BMC and benefit from:

- fast, convenient online submission

- thorough peer review by experienced researchers in your field

- rapid publication on acceptance

- support for research data, including large and complex data types

- gold Open Access which fosters wider collaboration and increased citations

- maximum visibility for your research: over $100 \mathrm{M}$ website views per year

At BMC, research is always in progress.

Learn more biomedcentral.com/submissions 